US Army Corps

of Engineers ${ }_{\circledast}$

Engineer Research and

Development Center

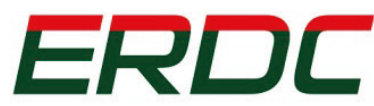

INNOVATIVE SOLUTIONS for a safer, better world

Rapid Airfield Damage Repair (RADR) Program

\title{
Modified Light-Duty AM2 Capability Assessment
}

Nolan R. Hoffman and Lyan Garcia

June 2018 
The U.S. Army Engineer Research and Development Center (ERDC) solves the nation's toughest engineering and environmental challenges. ERDC develops innovative solutions in civil and military engineering, geospatial sciences, water resources, and environmental sciences for the Army, the Department of Defense, civilian agencies, and our nation's public good. Find out more at www.erdc.usace.army.mil.

To search for other technical reports published by ERDC, visit the ERDC online library at http://acwc.sdp.sirsi.net/client/default. 


\section{Modified Light-Duty AM2 Capability Assessment}

Nolan R. Hoffman and Lyan Garcia

Geotechnical and Structures Laboratory

U.S. Army Engineer Research and Development Center

3909 Halls Ferry Road

Vicksburg, MS 39180-6199

Final report

Approved for public release; distribution is unlimited.

Prepared for Headquarters, Air Force Civil Engineer Center

Tyndall Air Force Base, FL 32403-5319

Under Project number 470802 


\section{Abstract}

The Modified Light-Duty AM2 matting was designed specifically for lightweight, remote-piloted aircraft (RPA) applications. An in-depth study was conducted previously by the U.S. Army Engineer Research and Development Center (ERDC) to characterize and model the mechanical performance of friction stir welding for use in fabrication of the lightweight RPA matting in conjunction with a full-scale test on the Modified Light-Duty AM2 matting system. The study validated the matting's performance when subjected to simulated RPA and support vehicle traffic over a subgrade with a California Bearing Ratio (CBR) of 6 . To understand the full potential of the Modified Light-Duty AM2, a fullscale evaluation was performed with contingency $\mathrm{C}-17$ and standard (below maximum) F-15E aircraft loads over a subgrade with a CBR of 6. The test results revealed that the connection between the mat core and the end connector is not strong enough to support loads heavier than RPA traffic. The overlap/underlap end connectors effectively sheared off from the mat core for both test vehicles. Even so, the mat cores showed minimal structural damage from the applied traffic.

DISCLAIMER: The contents of this report are not to be used for advertising, publication, or promotional purposes. Citation of trade names does not constitute an official endorsement or approval of the use of such commercial products. All product names and trademarks cited are the property of their respective owners. The findings of this report are not to be construed as an official Department of the Army position unless so designated by other authorized documents. 


\section{Contents}

Abstract
Figures and Tables.

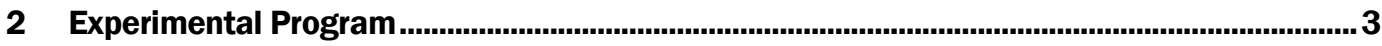

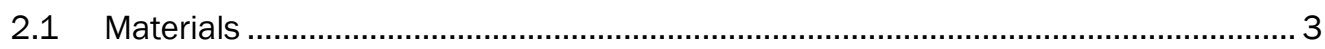

2.1.1 Modified Light-Duty AM2 mat.......................................................................... 3

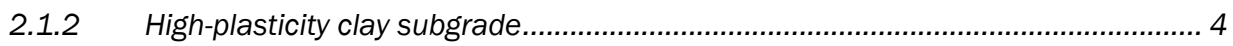

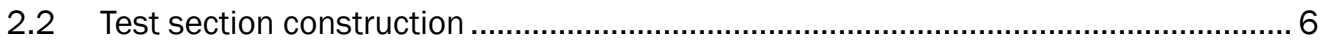

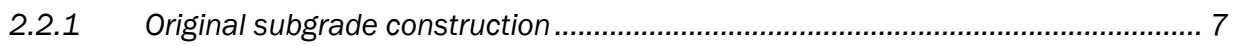

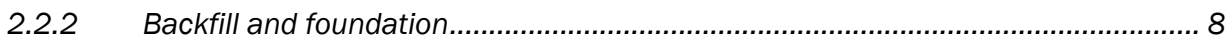

2.2.3 Subgrade reconstruction ................................................................................. 10

2.2.4 Mat installation ................................................................................................. 11

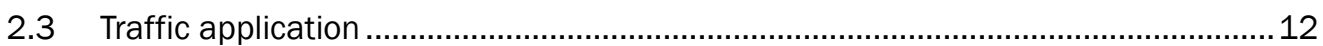

2.3.1 C-17 load cart....................................................................................................... 13

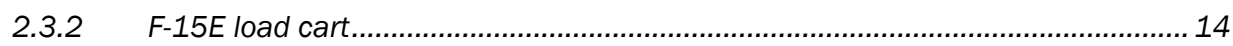

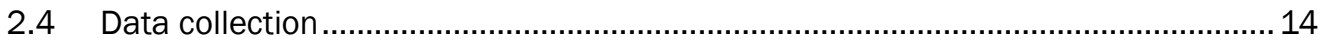

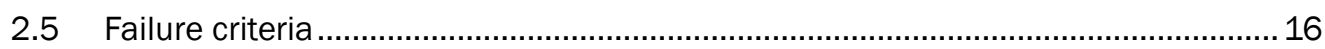

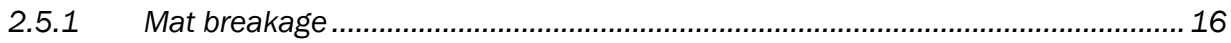

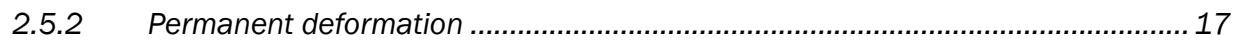

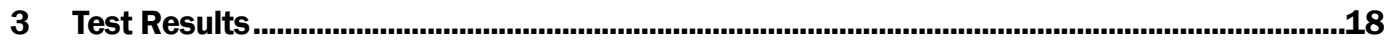

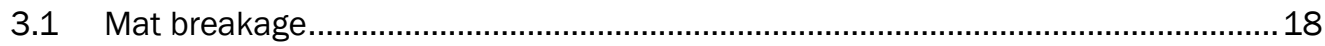

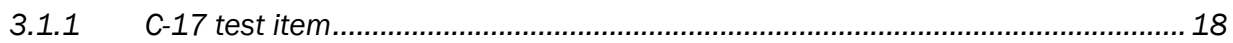

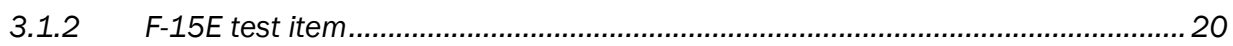

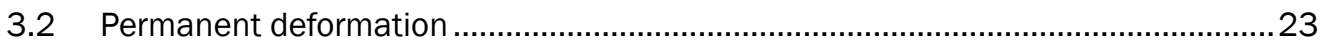

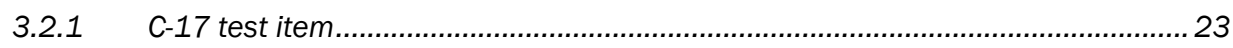

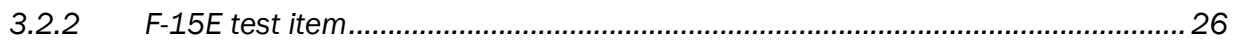

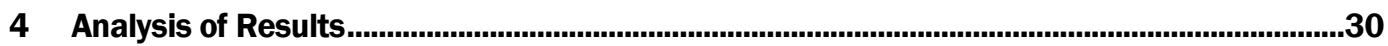

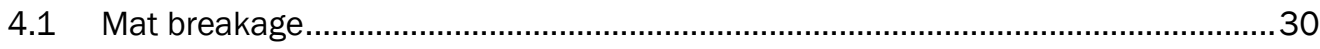

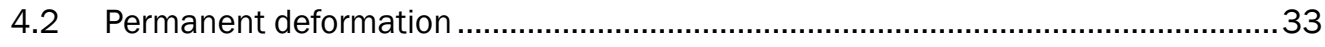

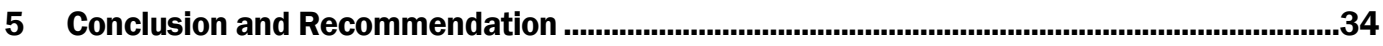

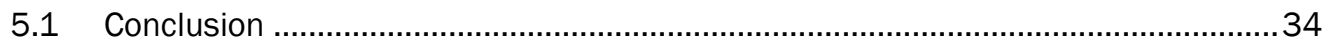

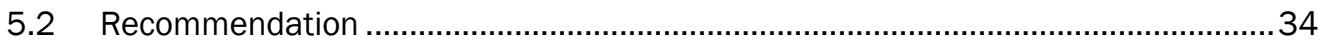




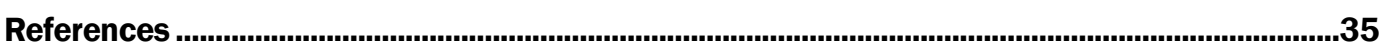
Report Documentation Page 


\section{Figures and Tables}

\section{Figures}

Figure 1. Modified Light-Duty AM2 panels.....................................................................................

Figure 2. Classification data for Vicksburg Buckshot $\mathrm{CH}$................................................................

Figure 3. Density vs. moisture data for Vicksburg Buckshot $\mathrm{CH}$. ................................................... 5

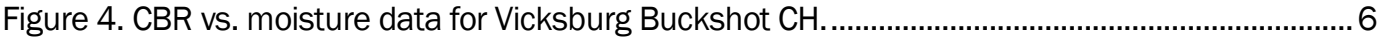

Figure 5. Profile view of test section subgrade. .............................................................................. 7

Figure 6. Classification data for low plasticity silt (ML) . ................................................................... 8

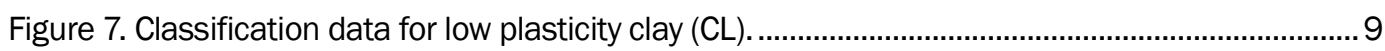

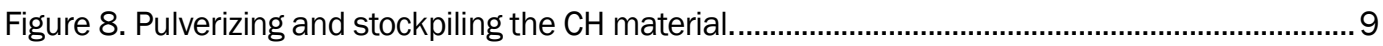

Figure 9. Spreading and compacting the $\mathrm{CH}$ material..................................................................

Figure 10. Assembled test section. ..................................................................................................12

Figure 11. Layout of test section..............................................................................................13

Figure 12. Single wheel C-17 traffic pattern.................................................................................14

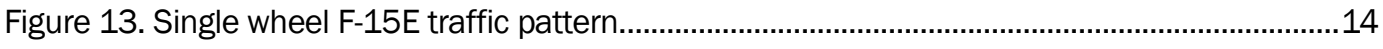

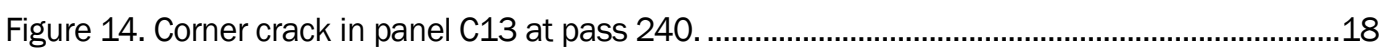

Figure 15. Weld crack and top skin tears in panel C33 after 480 passes. ......................................19

Figure 16. Overlap/underlap connector damage on panel C33 after 660 passes..........................19

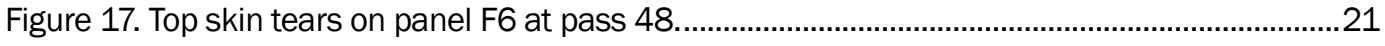

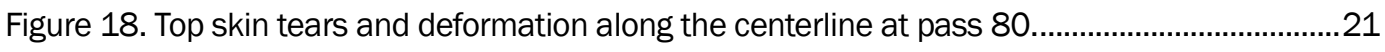

Figure 19. Top skin tears (left) and corner cracks (right) along centerline at pass 128...................22

Figure 20. Weld crack and skin tears on panel F6 after 152 passes. ...............................................22

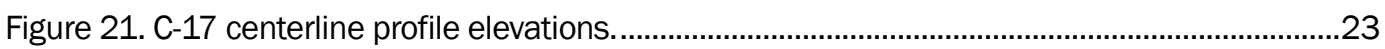

Figure 22. C-17 subgrade centerline profile elevations. ......................................................................2

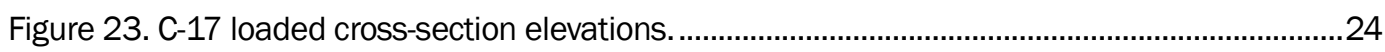

Figure 24. C-17 unloaded cross-section elevations........................................................................2

Figure 25. C-17 subgrade cross-section elevations. ……………………………………………...2

Figure 26. C-17 maximum deformation vs. pass level....................................................................26

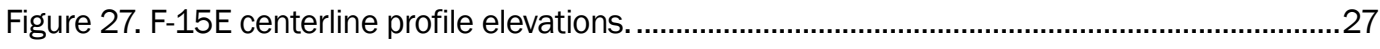

Figure 28. F-15E subgrade centerline profile elevations................................................................2

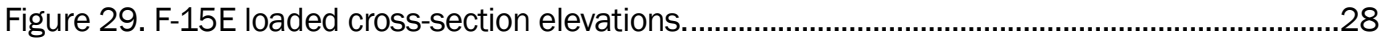

Figure 30. F-15E unloaded cross-section elevations. .....................................................................28

Figure 31. F-15E subgrade cross-section elevations. ...................................................................29

Figure 32. F-15E maximum deformation vs. pass level. .................................................................29

Figure 33. Complete separation of the overlap/underlap connector on panel C33. ........................30

Figure 34. Female hinge connector crack in panel C37. .................................................................31

Figure 35. Overlap/underlap connector separation. ....................................................................32

Figure 36. Sketch of the overlap/underlap connector's weld support tabs. ……….........................32 


\section{Tables}

Table 1. Modified Light-Duty AM2 and AM2 mat properties............................................................. 4

Table 2. Laboratory tests performed on $\mathrm{CH}$ material. ...................................................................... 4

Table 3. Tests performed on each installed lift..............................................................................10

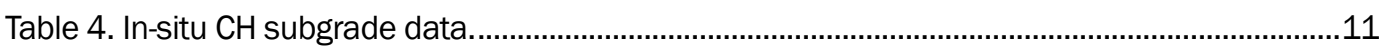

Table 5. C-17 data collection intervals. ................................................................................15

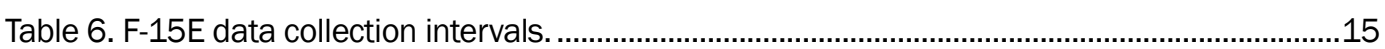

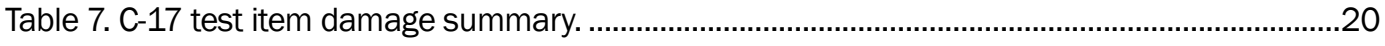

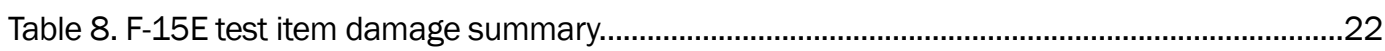




\section{Preface}

This study was conducted for the U.S. Air Force Civil Engineer Center (AFCEC) under the Rapid Airfield Damage Repair (RADR) Program. The technical monitor was Mr. Jeb S. Tingle.

The work was performed by the Airfields and Pavements Branch (GMA) of the Engineering Systems and Materials Division (GM), U.S. Army Engineer Research and Development Center, Geotechnical and Structures Laboratory (ERDC-GSL). At the time of publication, Dr. Timothy W. Rushing was Chief, CEERD-GMA; Dr. Gordon W. McMahon was Chief, CEERD-GM; and Mr. R. Nicholas Boone, CEERD-GVT, was the Technical Director for Force Projection and Maneuver Support. The Deputy Director of ERDC-GSL was Dr. William P. Grogan, and the Director was Mr. Bartley P. Durst.

COL Bryan S. Green was the Commander of ERDC, and Dr. David W. Pittman was the Director. 


\section{Unit Conversion Factors}

\begin{tabular}{|l|c|l|}
\hline Multiply & By & To Obtain \\
\hline feet & 0.3048 & meters \\
\hline inches & 0.0254 & meters \\
\hline pounds (force) & 4.448222 & newtons \\
\hline pounds (force) per square foot & 47.88026 & pascals \\
\hline pounds (force) per square inch & 6.894757 & kilopascals \\
\hline pounds (mass) & 0.45359237 & kilograms \\
\hline pounds (mass) per cubic foot & 16.01846 & kilograms per cubic meter \\
\hline square feet & 0.09290304 & square meters \\
\hline square inches & 6.4516 E-04 & square meters \\
\hline
\end{tabular}




\section{Introduction}

\subsection{Background}

Expedient surfacing systems have been used since the 1940s to rapidly construct new and expand existing airfield facilities during contingency operations. The primary expeditionary airfield surfacing for the U.S. military is AM2 mat, which has been in service as a temporary runway, taxiway, and parking apron surface since the 1960s. Although AM2 has a long history of satisfactory performance, the weight and dimensions are limiting factors in its deployability. Typically, aircraft load limits are exceeded without approaching cubage limits and are requiring an excessive number of aircraft to deliver AM2 to contingency locations.

In order to address AM2's logistical challenges, the AMX program was initiated by the U.S. Air Force to develop a lightweight replacement for AM2 matting. The joint services agreed upon a desired design thickness of 1.25 in., a maximum desired unit weight of $3.8 \mathrm{lbf} / \mathrm{ft}^{2}$, and required that the new mat be configured for optimal packing on a 463L pallet, which has useable dimensions of $104 \mathrm{in}$. by $84 \mathrm{in}$. In addition, the mat system was required to sustain at least 1,500 passes of $\mathrm{F}-15 \mathrm{E}$ traffic over a 6 California Bearing Ratio (CBR) subgrade. The pass requirement was determined by baseline testing of AM2 (Rushing and Tingle 2007). Currently, no commercial metal mat has been able to meet these requirements; therefore, the U.S. Army Engineer Research and Development Center (ERDC) is still developing matting solutions for the replacement of AM2 with a lighter weight, logistically friendly alternative.

The logistical issues of AM2 are further compounded by the U.S. military's increased demand for remote-piloted aircraft (RPA), which have significantly reduced wheel loads compared to piloted aircraft. Thus, the effectiveness of AM2 in support of RPA operations is also diminished by the excessive logistical requirements. A lighter airfield mat would reduce airlift requirements and provide a substantial increase in airfield expansion capability, leading to a more effective staging of forward bases for RPA.

Modified Light-Duty AM2 was developed specifically for RPA applications, while also weighing just under $4.0 \mathrm{lbf} / \mathrm{ft}^{2}$. It is a modified version of a legacy matting system designed by Harvey Aluminum Company in the early 1970s, 
referred to as Light-Duty AM2. The development and full-scale RPA testing results of Modified Light-Duty AM2 are documented in Hoffman et al. (2017). The test results showed that Modified Light-Duty AM2 was able to support 1,500 passes of MQ-9A Reaper traffic and 500 passes of P-19 support vehicle traffic with zero damage and negligible deformation.

Despite the successful performance of Modified Light-Duty AM2 in supporting RPA test loads, the full capability of the matting was still unknown. Considering that Modified Light-Duty AM2 was designed for RPA traffic, it was unlikely that the matting system would be able to meet the traffic requirements of the AMX program; however, it did meet the size requirement and was very close to the weight requirement. Therefore, the ERDC conducted a full-scale experiment utilizing contingency $\mathrm{C}-17$ traffic and standard, or reduced-load, F-15E traffic. The evaluation was performed in the Hangar 2 Pavement Testing Facility at the ERDC in Vicksburg, MS. A successful performance was considered as the ability to sustain at least 1,500 passes of $\mathrm{C}-17$ traffic or 1,500 passes of $\mathrm{F}-15 \mathrm{E}$ traffic without failing due to mat breakage or surface deformation.

\subsection{Objective}

The objective of this project was to evaluate the Modified Light-Duty AM2 matting as a potential AMX solution to understand the full capability of the matting. In order to do so, researchers constructed a test section containing two separate test items, one for $\mathrm{C}-17$ and one for $\mathrm{F}-15$ testing. For the purpose of this report, the aircraft loads that were chosen were (1) a single $\mathrm{C}-17$ wheel and tire loaded with $37,260 \mathrm{lb}$ and inflated to $142 \mathrm{lb} /$ in. $^{2}$ and (2) a single F-15E wheel and tire loaded with $26,750 \mathrm{lb}$ and inflated to $325 \mathrm{lb} /$ in. $^{2}$ 


\section{Experimental Program}

\subsection{Materials}

\subsubsection{Modified Light-Duty AM2 mat}

Modified Light-Duty AM2 matting in new, unused condition was used for testing. The matting was visually inspected to ensure the materials were not damaged prior to the test. Modified Light-Duty AM2 is comprised of an extruded AA6061-T6 core that is friction stir welded to extruded end connectors of the same material. The core has vertical I-beam stiffeners encapsulated by a top and bottom skin to support aircraft loads.

Modified Light-Duty AM2 has been optimized to fit the $463 \mathrm{~L}$ pallet. The global dimensions of Modified Light-Duty AM2 panels (Figure 1) measure 102 in. long by 21 in. wide by 1.5 in. thick. The Modified-Light Duty AM2 design originated from Light-Duty AM2, which was a legacy system created by Harvey Aluminum Company in the 1970s. Additional details regarding the development of Modified Light-Duty AM2 can be found in Hoffman et al. (2017).

Figure 1. Modified Light-Duty AM2 panels.

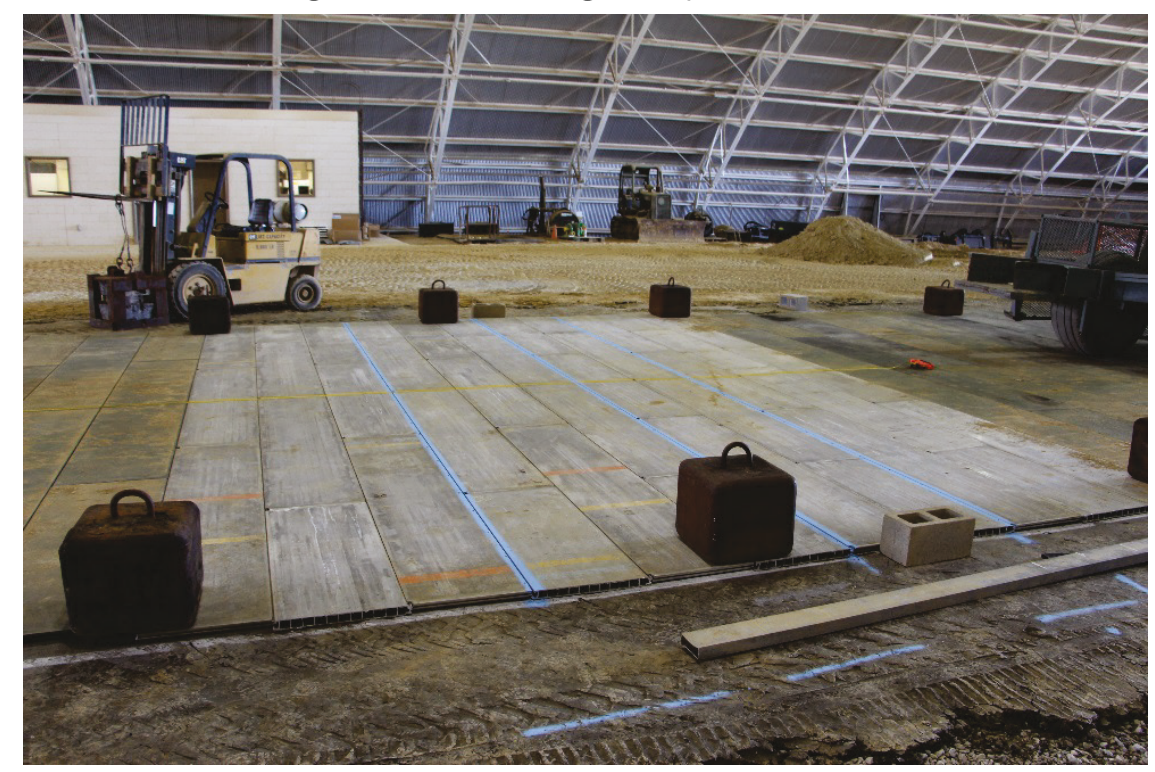

Modified Light-Duty AM2 utilizes the same connection system as AM2 matting. Standard AM2 served as overruns in between and on the ends of the two test items since no special connections were required. The longitudinal direction of the matting connects via overlap/underlap 
connectors that create a rectangular slot for a locking bar when connected. The transverse direction of the matting connects via male and female hinge connectors. Approximately $972 \mathrm{ft}^{2}$ of the Modified Light-Duty AM2 was required to construct the two test items. In total, 56 full panels and 20 half panels were required. Table 1 provides dimensions for both Modified Light-Duty AM2 and traditional AM2.

Table 1. Modified Light-Duty AM2 and AM2 mat properties.

\begin{tabular}{|l|c|c|c|c|}
\hline Mat & \multicolumn{2}{|c|}{ Modified Light-Duty AM2 } & \multicolumn{2}{|c|}{ AM2 } \\
\hline Size & Half & Full & Half & Full \\
\hline Length (in.) & 51 & 102 & 72 & 144 \\
\hline Width (in.) & 21 & 21 & 24 & 24 \\
\hline Thickness (in.) & 1.5 & 1.5 & 1.5 & 1.5 \\
\hline Unit Weight (lb/ft ${ }^{2}$ ) & 4.0 & 4.0 & 6.3 & 6.1 \\
\hline
\end{tabular}

\subsubsection{High-plasticity clay subgrade}

A high-plasticity clay $(\mathrm{CH})$ material was selected as the subgrade material for this test because of the ability to control its strength characteristics within a narrow range. The material that was used for this test had already been prepared and used in a previous ERDC experiment. The $\mathrm{CH}$ material was procured from a source local to Vicksburg, MS (Buford Construction Co.) and was subjected to a suite of post-traffic laboratory tests listed in Table 2. Classification data for the $\mathrm{CH}$ are shown in Figure 2. CBR-moisture content and moisture-density relationships are shown in Figures 3 and 4, respectively. These data were used to determine the target moisture content and dry density required to obtain the target CBR of 6 . According to Figure 4, the target moisture content was $33.5 \%$ to achieve a CBR of 6 . The expected dry density for quality control at $33.5 \%$ moisture content was $87 \mathrm{lb} / \mathrm{ft} 3$. Laboratory testing was conducted by the Materials Testing Center at ERDC.

Table 2. Laboratory tests performed on $\mathrm{CH}$ material.

\begin{tabular}{|l|l|}
\hline Test Name & ASTM \\
\hline Standard Practice for Classification of Soils for Engineering Purposes (USCS) & D 2487 \\
\hline Standard Test Method for Particle Size Analysis of Soils & D 422 \\
\hline Standard Test Method for Laboratory Compaction Characteristics of Soil Using Modified Effort & D 1557 \\
\hline Standard Test Method for CBR of Laboratory Compacted Soils & D 1883 \\
\hline Standard Test Methods for Liquid Limit, Plastic Limit, and Plasticity Index of Soils & D 4318 \\
\hline
\end{tabular}


Figure 2. Classification data for Vicksburg Buckshot $\mathrm{CH}$.

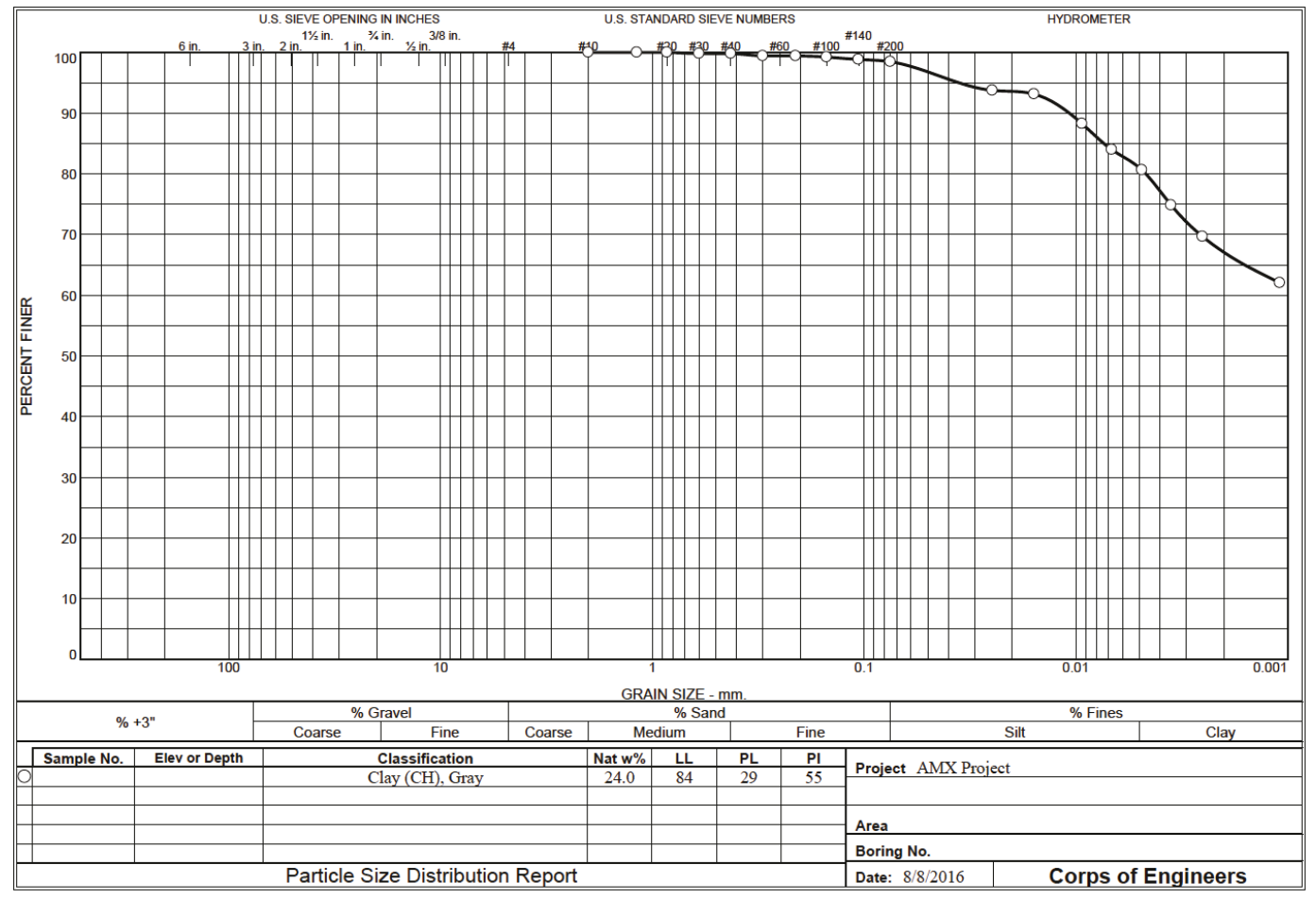

Figure 3. Density vs. moisture data for Vicksburg Buckshot $\mathrm{CH}$.

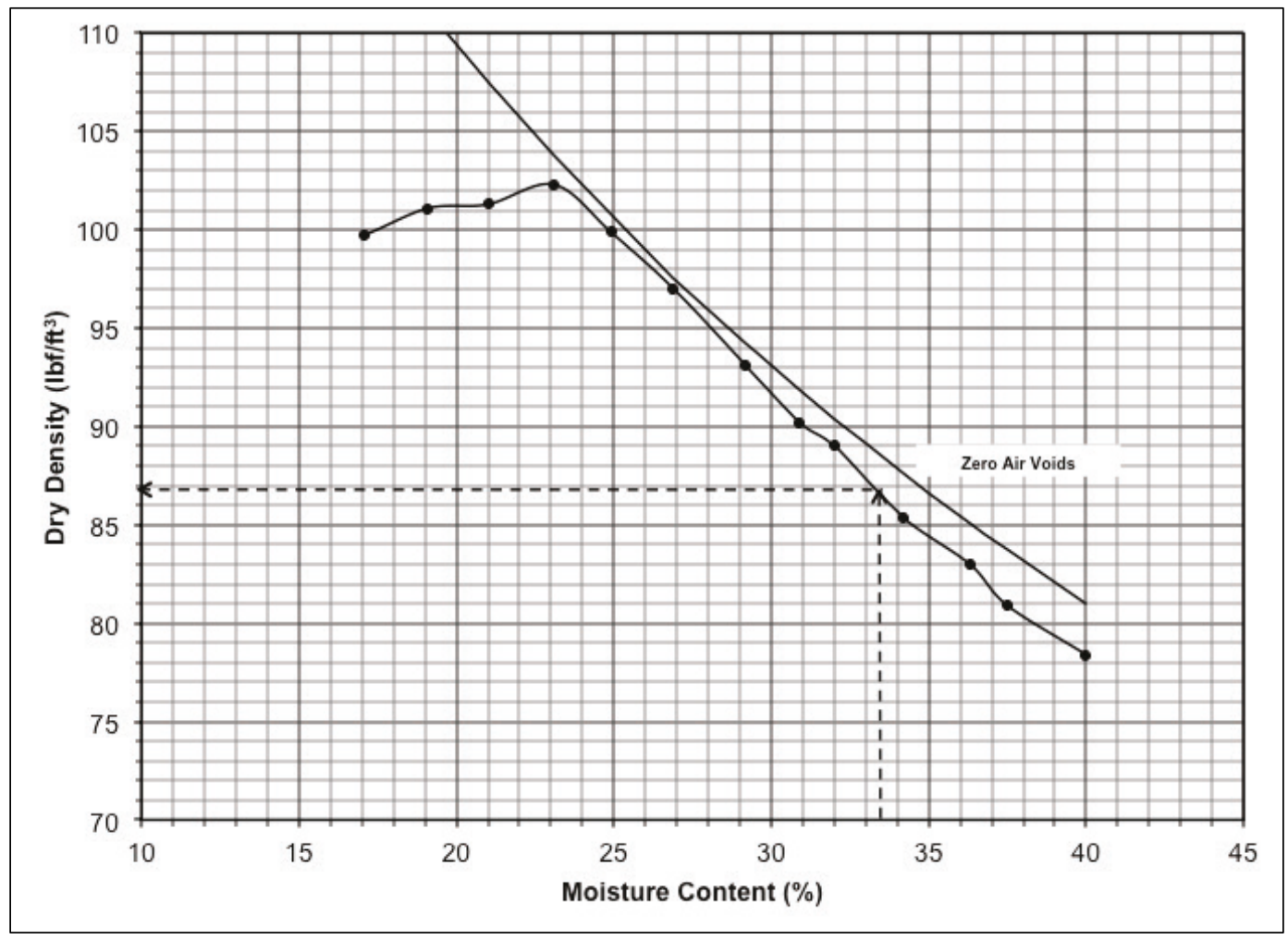


Figure 4. $\mathrm{CBR}$ vs. moisture data for Vicksburg Buckshot $\mathrm{CH}$.

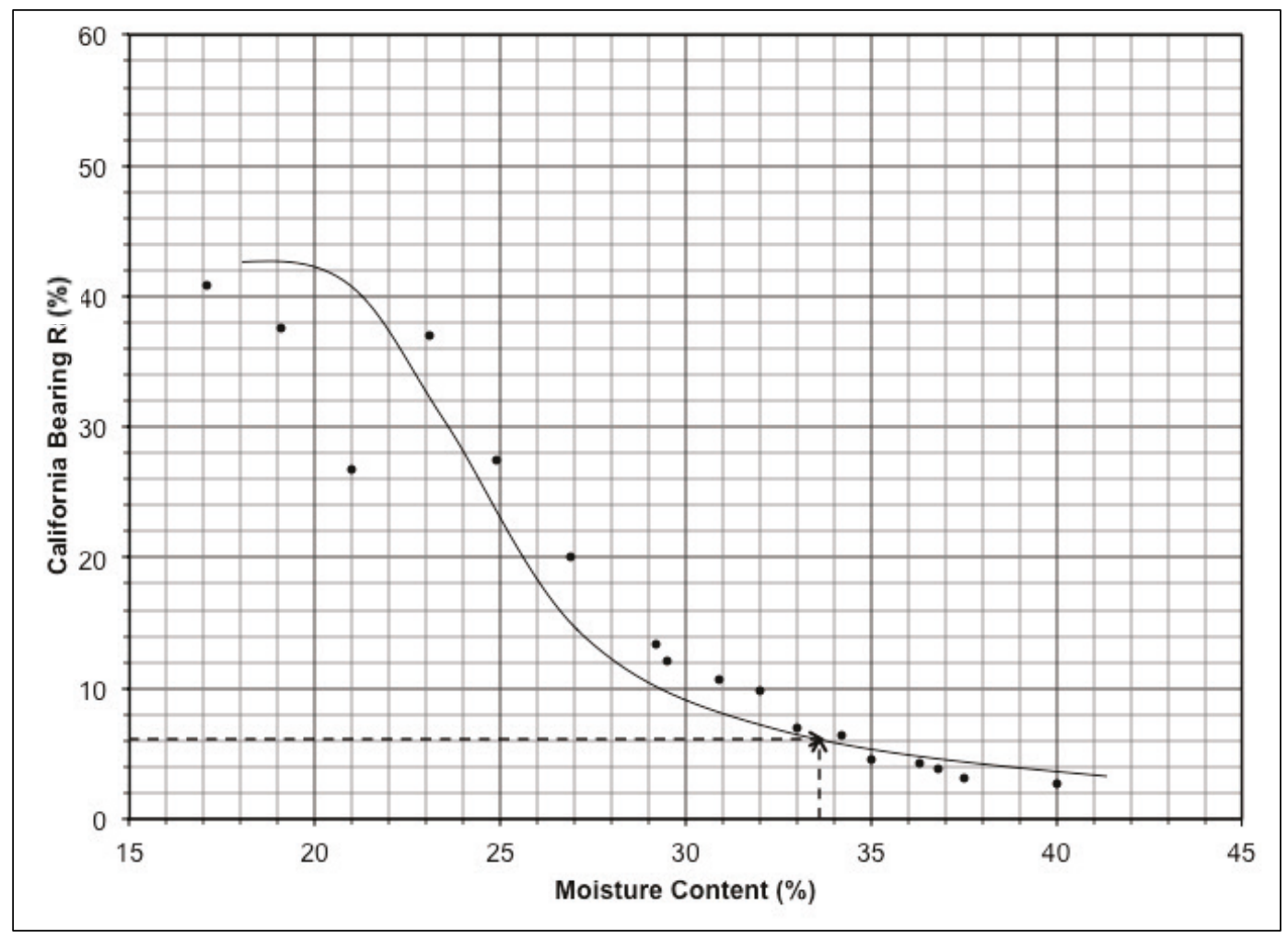

\subsection{Test section construction}

The tests were conducted on a full-scale section constructed and trafficked under shelter in the Hangar 2 Pavement Test Facility at the ERDC. Mat panels were placed directly over a 24 -in.-thick $\mathrm{CH}$ subgrade prepared to a CBR of 6 . The subgrade was compacted over a foundation prepared with a low plasticity silt (ML), which was placed over the natural low plasticity clay (CL) foundation at the Hangar 2 facility. A general profile of the test section is shown in Figure 5. 
Figure 5. Profile view of test section subgrade.

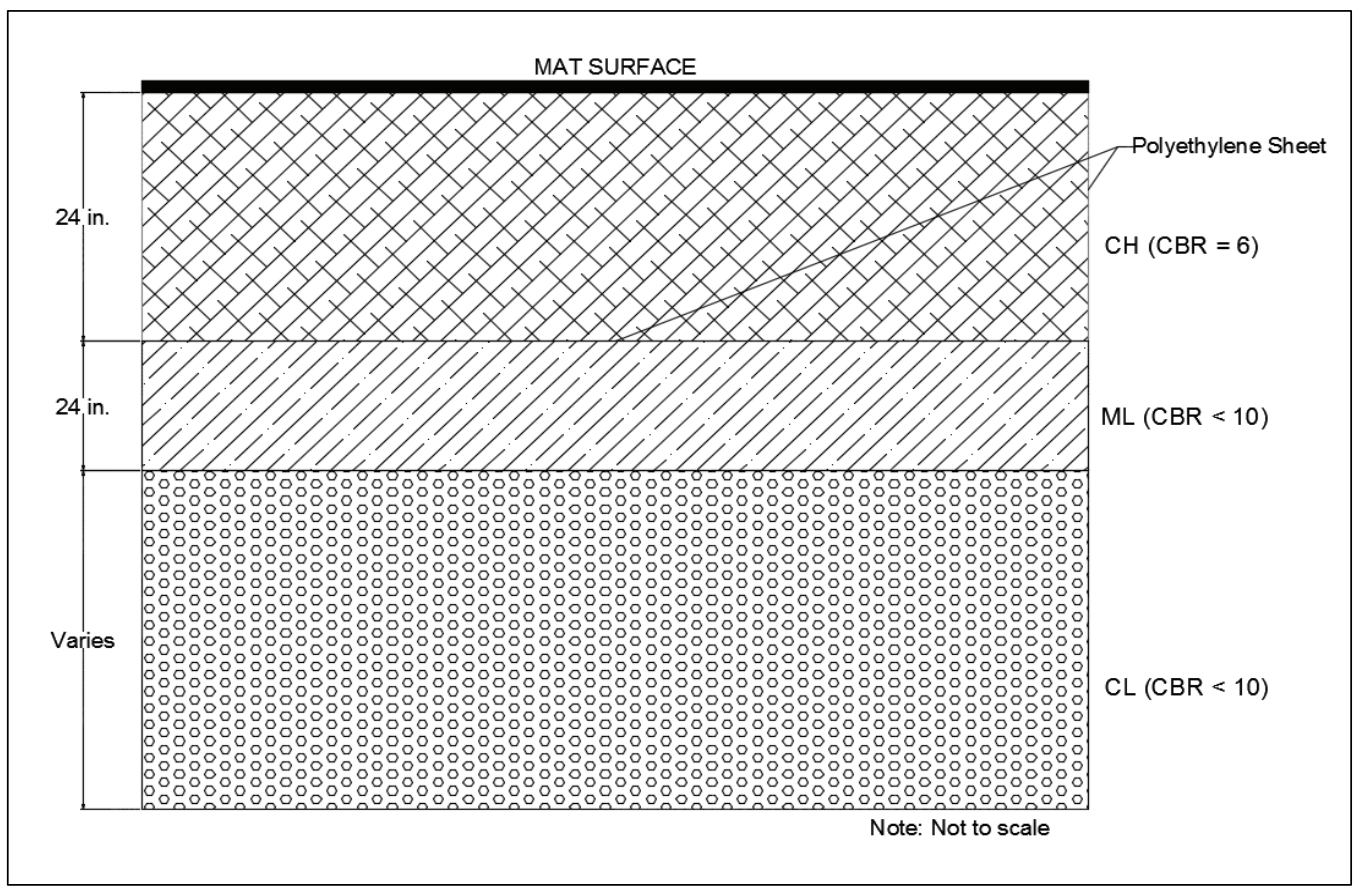

\subsubsection{Original subgrade construction}

The test section was constructed over an existing subgrade within the Hangar 2 testing facility. The original test section was constructed by excavating a 75 -ft-long by 27 -ft-wide test pit to a depth of $3 \mathrm{ft}$ below the existing finished grade. The test pit was backfilled with one 12-in. (compacted) lift of low plasticity silt (ML), according to ASTM D 2487 (2011). The lift of the ML material was leveled with a bulldozer and compacted with a pneumatic roller and a vibratory steel-wheel compactor to ensure that the subgrade was constructed over a stable foundation. Dynamic cone penetrometer (DCP) tests (ASTM D6951) were conducted to estimate insitu bearing capacity. Once compacted, the bottom and sides of the test pit were lined with impervious 6-mil polyethylene sheeting to minimize moisture migration from the 24 in. of new $\mathrm{CH}$ soil serving as the test section subgrade. Classification data are provided in Figure 6. 
Figure 6. Classification data for low plasticity silt (ML).

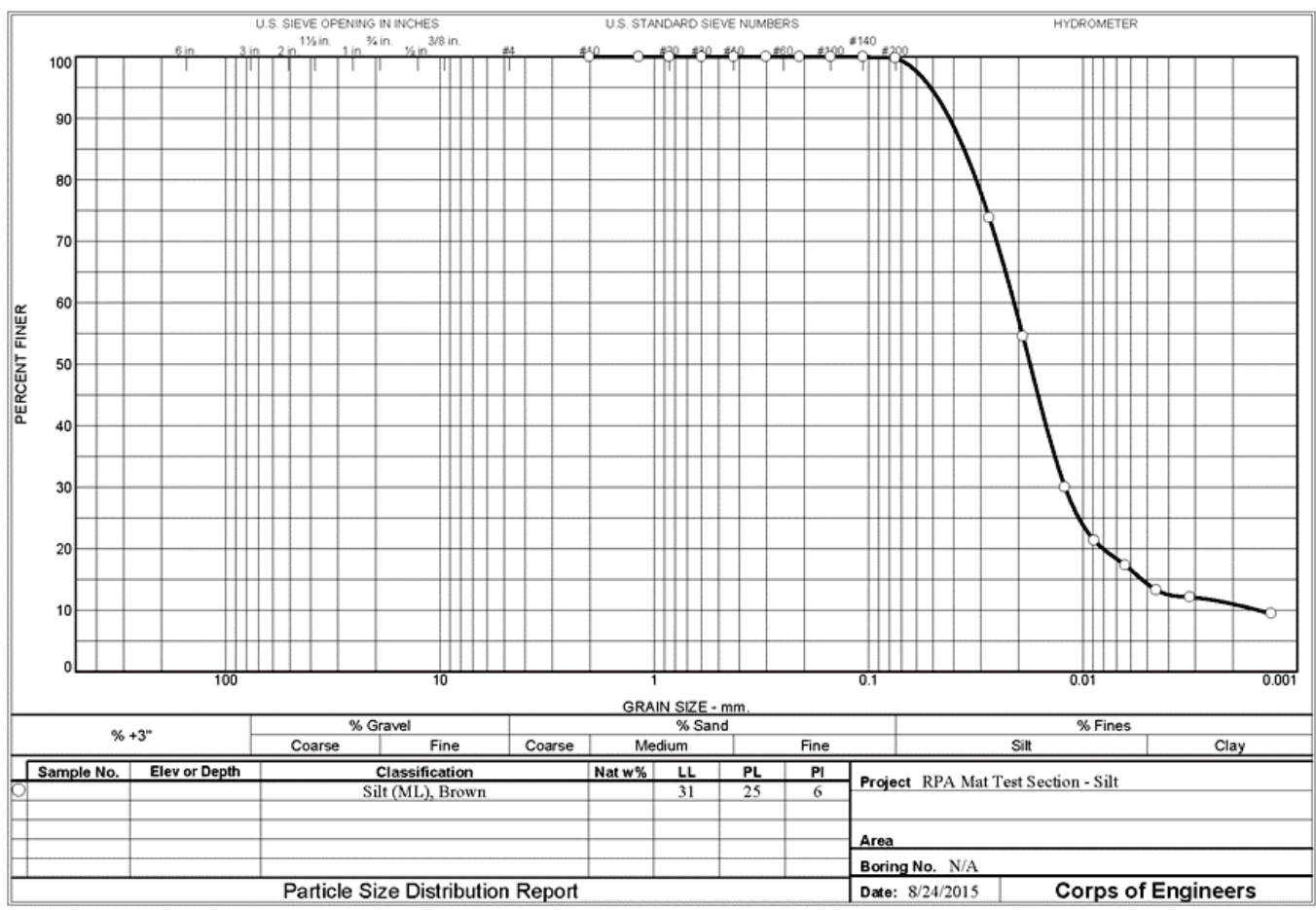

\subsubsection{Backfill and foundation}

The natural foundation material at the Hangar 2 test facility was classified as a low plasticity clay (CL), according to ASTM D 2487 (2011).

Classification data are provided in Figure 7.

The $\mathrm{CH}$ material was processed at a preparatory site next to Hangar 2 by spreading the material to a uniform 12 in. thickness, pulverizing the material with a rotary mixer, adjusting the moisture content, pulverizing the material again, and stockpiling (Figure 8). This was an iterative process necessary to achieve a uniform distribution of moisture throughout the material. Once the $\mathrm{CH}$ had been processed to the target moisture content, it was placed in the test section, spread by a bulldozer in 8-in.-thick lifts, and compacted with a pneumatic roller to a thickness of 6 in. (Figure 9). 
Figure 7. Classification data for low plasticity clay (CL).

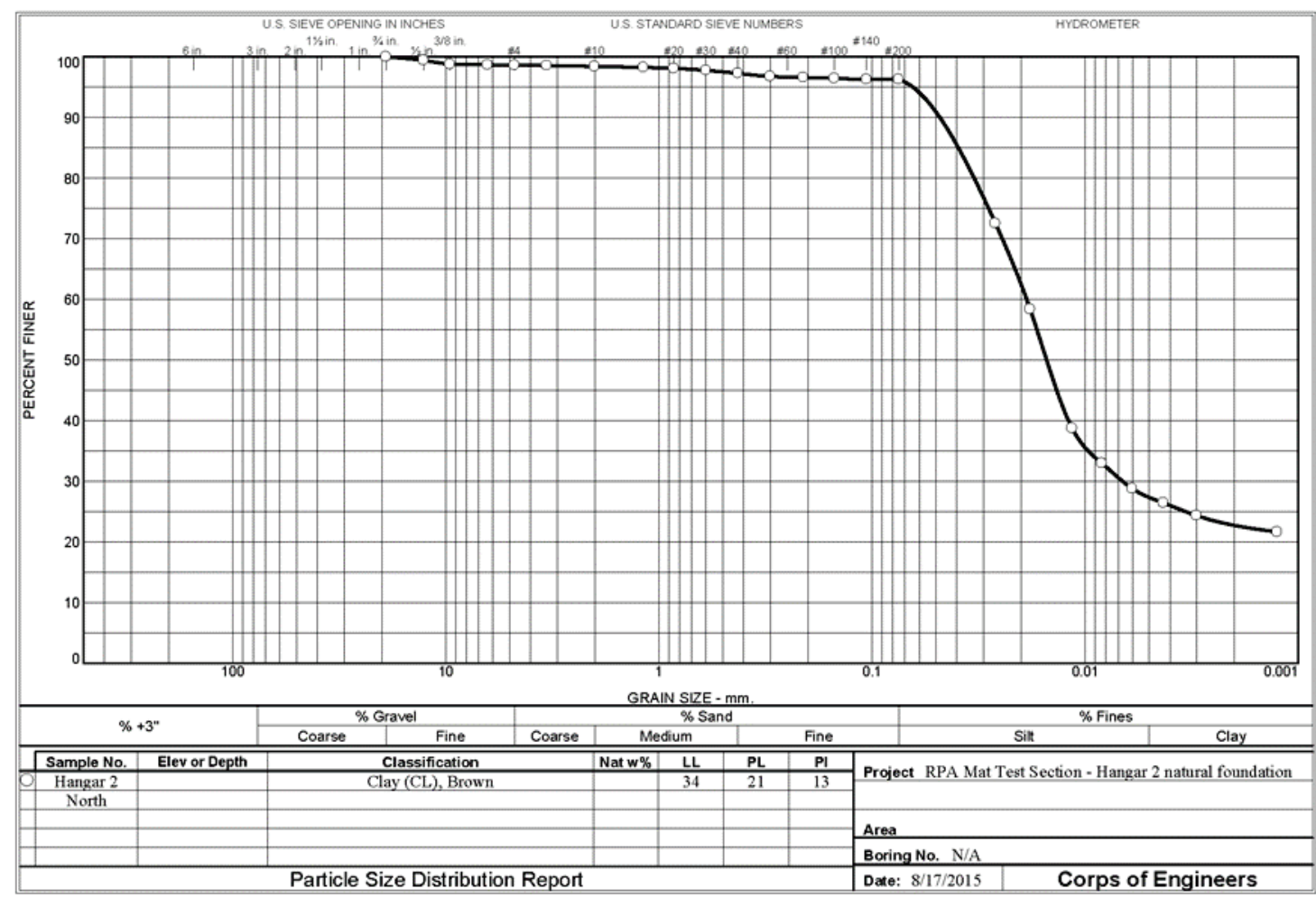

Figure 8. Pulverizing and stockpiling the $\mathrm{CH}$ material.

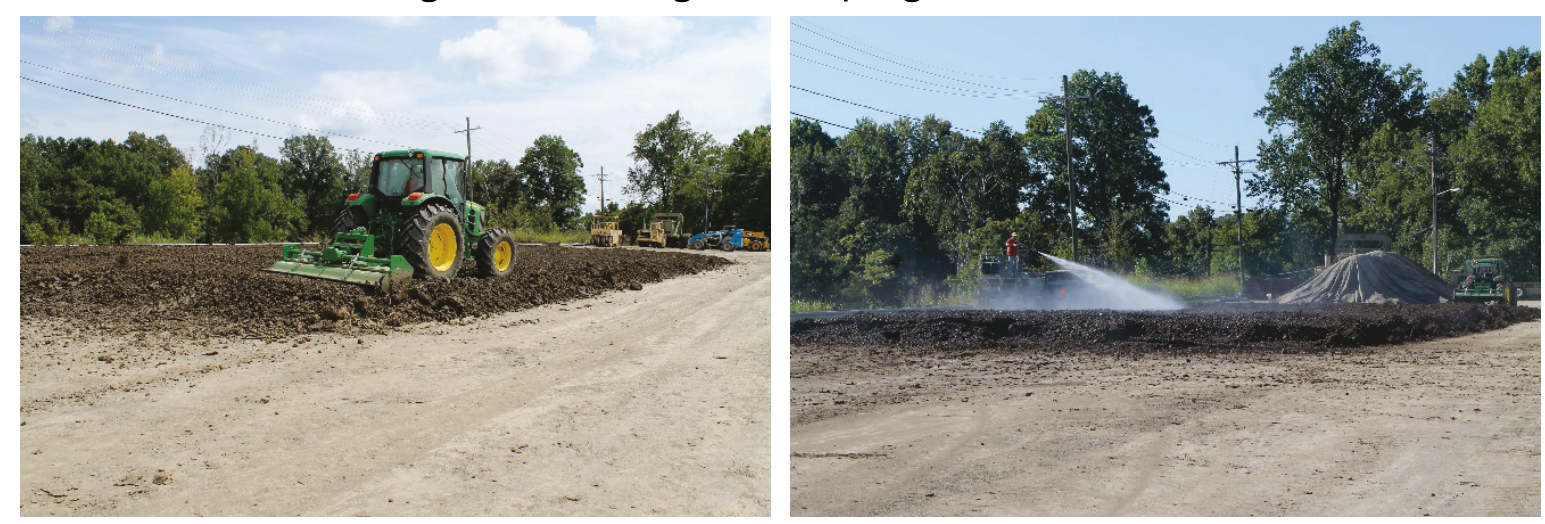

Figure 9. Spreading and compacting the $\mathrm{CH}$ material.
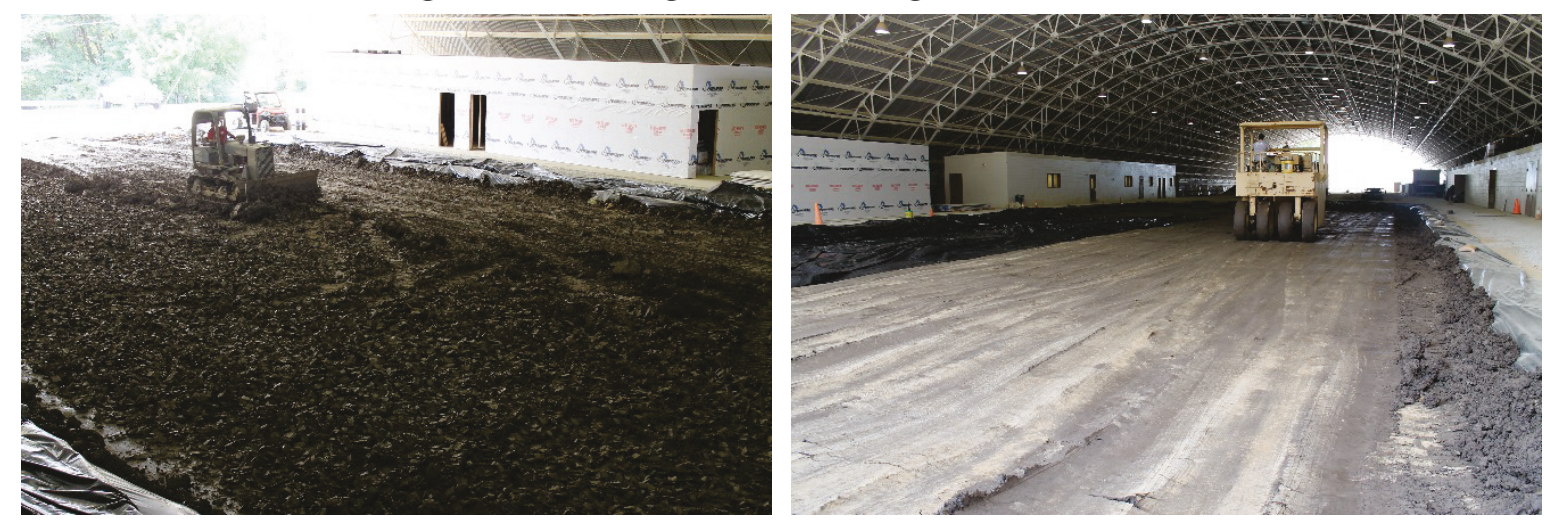
Each compacted lift was subjected to the test methods listed in Table 3 to characterize the compacted subgrade properties and verify that target values had been met. If the average pretest CBR of a lift differed from the target value by more than +1.0 or -0.5 CBR, the lift was reconstituted. Each lift was surveyed to obtain an average thickness. After data collection, the surface of each lift was scarified an average depth of $1 \mathrm{in}$. with a rotary mixer prior to placement of the next lift to facilitate bonding at the interface. Once fully constructed, the subgrade surface was graded to allow a suitable surface for mat installation.

Table 3. Tests performed on each installed lift.

\begin{tabular}{|l|c|c|c|c|}
\hline Test Name & Test Number & $\begin{array}{c}\text { Pretest } \\
\text { Subgrade }\end{array}$ & $\begin{array}{c}\text { Posttest } \\
\text { Subgrade }\end{array}$ & $\begin{array}{c}\text { Excavation \& } \\
\text { Silt Backfill }\end{array}$ \\
\hline $\begin{array}{l}\text { Standard Test Method for Density of Soil in Place by the } \\
\text { Drive Cylinder }\end{array}$ & ASTM D 2937 & $\mathrm{X}$ & & \\
\hline $\begin{array}{l}\text { Standard Test Methods for Density of Soil and Soil } \\
\text { Aggregate in Place by Nuclear Methods (Shallow Depth) }\end{array}$ & ASTM D 6938 & $\mathrm{X}$ & $\mathrm{X}$ & $\mathrm{X}$ \\
\hline $\begin{array}{l}\text { Standard Test Method for Laboratory Determination of } \\
\text { Water Content of Soil and Rock Mass }\end{array}$ & ASTM D 2216 & $\mathrm{X}$ & $\mathrm{X}$ & $\mathrm{X}$ \\
\hline $\begin{array}{l}\text { Standard Test Method for Use of the Dynamic Cone } \\
\text { Penetrometer in Shallow Pavement Applications }\end{array}$ & ASTM D 6951 & $\mathrm{X}$ & $\mathrm{X}$ & $\mathrm{X}$ \\
\hline $\begin{array}{l}\text { Standard Test Method for Determining the California } \\
\text { Bearing Ratio of Soils }\end{array}$ & CRD-C654-95 & $\mathrm{X}$ & $\mathrm{X}$ & $\mathrm{X}$ \\
\hline
\end{tabular}

\subsubsection{Subgrade reconstruction}

$\mathrm{CBR}$, nuclear gage, and DCP tests were conducted $12 \mathrm{ft}$ and $20 \mathrm{ft}$ north and south from the midpoint of the entire test section. The remaining tests listed in Table 3 were conducted at offset locations. If the average CBR of a lift differed from the target value by more than +1.0 or $-0.5 \mathrm{CBR}$, the lift would have been removed and reprocessed.

Once trafficking was completed, posttest forensics were conducted at the same locations to determine the depth of subgrade that might have undergone gradual drying and possible densification under traffic. Some increase in CBR was expected because of thixotropic properties of clay structures and gradual drying and densification during trafficking. Based on historic testing data, surface increases of less than 5 CBR and increases of less than 3 CBR at a depth of 6 in. are common and therefore acceptable (Rushing and Tingle 2007; Rushing et al. 2012). Properties for the $\mathrm{CH}$ subgrade prior to installing the mat and after the completion of trafficking on each test item are shown in Table 4. 
Table 4. In-situ CH subgrade data.

\begin{tabular}{|c|c|c|c|c|c|c|}
\hline \multicolumn{7}{|c|}{ Pretest } \\
\hline & & & uclear Gage Test & & CBR Test & \\
\hline Item & Lift & Wet Density (pcf) & Dry Density (pcf) & Moisture (\%) & Oven Moisture (\%) & CBR \\
\hline \multirow{5}{*}{ F-15E } & Surface & 115.0 & 88.0 & 30.7 & 33.2 & 5.5 \\
\hline & $6 \mathrm{in.}$ & 116.7 & 85.0 & 37.3 & 34.5 & 5.9 \\
\hline & 12 in. & 117.4 & 88.6 & 32.6 & 32.1 & 7.5 \\
\hline & 18 in. & 116.6 & 86.0 & 35.6 & 34.6 & 6.4 \\
\hline & Average & 116.4 & 86.9 & 34.1 & 33.6 & 6.3 \\
\hline \multirow{5}{*}{$C-17$} & Surface & 116.6 & 90.7 & 28.6 & 33.8 & 5.8 \\
\hline & $6 \mathrm{in.}$ & 116.3 & 87.1 & 33.6 & 33.2 & 6.2 \\
\hline & $12 \mathrm{in.}$ & 115.0 & 88.6 & 29.8 & 34.0 & 7.0 \\
\hline & 18 in. & 111.0 & 82.4 & 34.8 & 34.0 & 5.8 \\
\hline & Average & 114.7 & 87.2 & 31.7 & 33.8 & 6.2 \\
\hline \multicolumn{7}{|c|}{ Posttest } \\
\hline & & \multicolumn{3}{|c|}{ Nuclear Gage Test } & \multicolumn{2}{|l|}{ CBR } \\
\hline Item & Lift & Wet Density (pcf) & Dry Density (pcf) & Moisture (\%) & Oven Moisture (\%) & CBR \\
\hline \multirow{3}{*}{ F-15E } & Surface & 116.2 & 87.9 & 32.3 & 35.2 & 6.7 \\
\hline & 6 in. & 117.2 & 89.3 & 31.4 & 34.3 & 7.9 \\
\hline & Average & 116.7 & 88.6 & 31.8 & 34.8 & 7.3 \\
\hline \multirow{3}{*}{ C-17 } & Surface & 112.8 & 85.0 & 32.7 & 33.8 & 7.9 \\
\hline & 6 in. & 117.9 & 90.0 & 31.1 & 34.1 & 7.3 \\
\hline & Average & 115.3 & 87.5 & 31.9 & 34.0 & 7.6 \\
\hline
\end{tabular}

\subsubsection{Mat installation}

The Modified Light-Duty AM2 mat system was placed in a standard brickwork pattern on the surface of the prepared subgrade section by an experienced labor crew. Starting in the southeast corner of the test section, the first mat panel was placed flat on the ground with the longest dimension perpendicular to the direction of traffic and the male hinge connector facing north. Moving west, the second panel was placed adjacent to the $21 \mathrm{in}$. section of the first panel, allowing the overlapping end connector to drop into position over the underlapping end connector. By design, once the two panels were in position, a rectangular slot was formed between the two end connectors, and an aluminum locking bar was inserted into the slot. This bar prevented the panels from separating under load. Moving west again, a third panel was placed in the same manner as the previous panel, completing the first row.

For the second row, the 102 in. female hinge connector was positioned onto the male hinge connector from the first panel and pivoted into place. The next panel was then installed by connecting the female hinge connector to the male hinge connector of the panels in the first row while allowing the overlapping end connector to pivot over and drop onto the underlapping end connector of the adjacent panel. Additionally, an aluminum locking bar was inserted into the rectangular slot formed 
between the underlapping and overlapping end connectors. The process was repeated until each mat test section was assembled in a brickwork configuration, with half panels on alternating ends of every other row. Each test item consisted of a total of 28 full panels and 10 half panels. Each test item spanned a total of $25.25 \mathrm{ft}$ wide by $18.8 \mathrm{ft}$ long. As in previous simulated aircraft testing of AM2 and other mat systems, $1,000 \mathrm{lb}$ steel weights were placed on the mats along each side of the test section to simulate a large expanse of matting as would be representative of a runway, a taxiway, or a parking apron. Used standard AM2 matting was assembled for overruns on the transitions to and from the mat sections. These were connected to the test section by using keylocks where possible. Figure 10 is a photograph of the assembled test section.

Figure 10. Assembled test section.

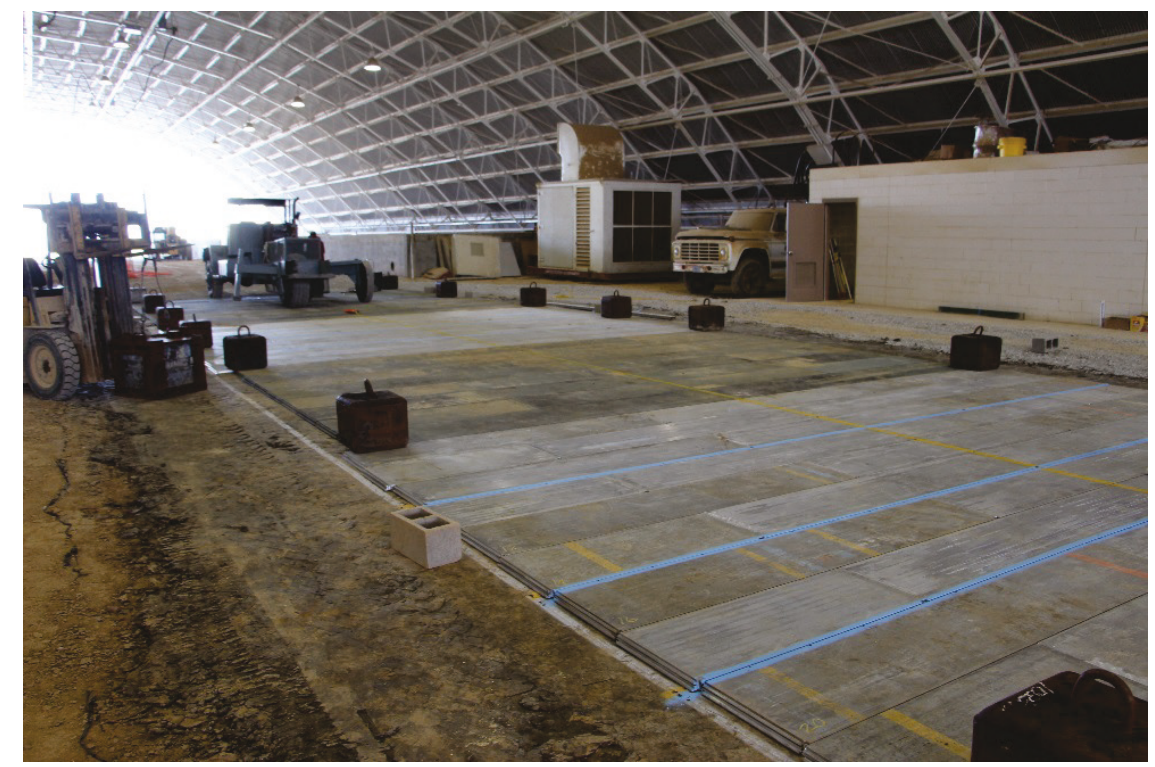

\subsection{Traffic application}

The test section was divided into a north and a south test item separated by used traditional AM2 matting available at the ERDC. A diagram of the layout of the full test section is shown in Figure 11. The north test item was designated for simulated $\mathrm{C}-17$ traffic. When the $\mathrm{C}-17$ trafficking ceased, the south test item was then trafficked with a simulated F-15E aircraft. 
Figure 11. Layout of test section.

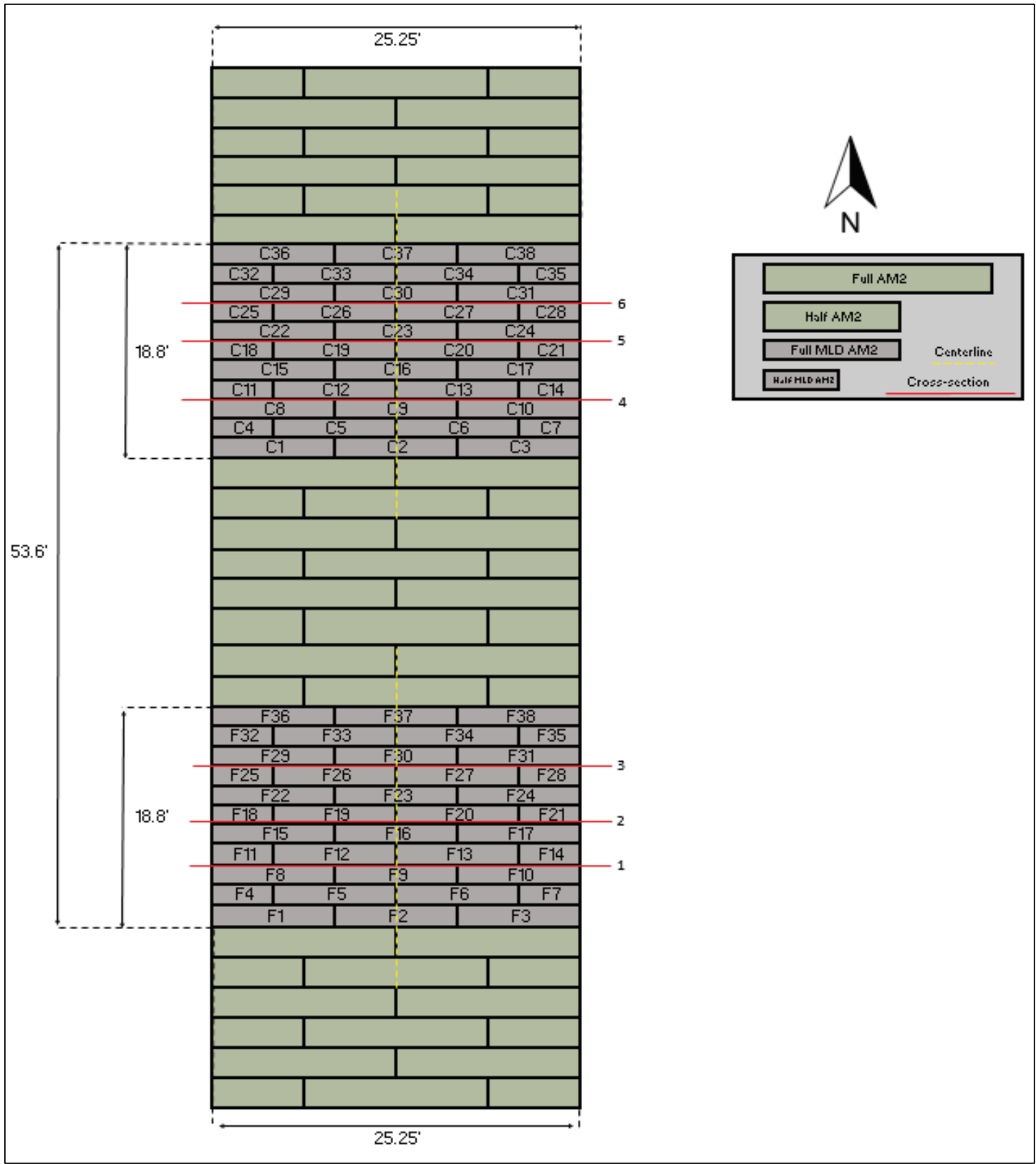

\subsubsection{C-17 load cart}

A specially designed single-wheel load cart was used to simulate C-17 aircraft traffic. The load cart was equipped with a 50 in. by 21 in. 20-ply tire inflated to $142 \mathrm{lbf} /$ in. $^{2}$ and loaded such that the test wheel supported approximately $37,260 \mathrm{lb}$. This loading was chosen to model the contingency loading for $\mathrm{C}-17$ aircraft. Traffic was applied on the test item in a normally distributed traffic pattern. The traffic pattern and wander width are shown in Figure 12. A three-lane traffic pattern was chosen in order to best simulate the correct pass to coverage ratio for the $\mathrm{C}-17$. 
Figure 12. Single wheel C-17 traffic pattern.

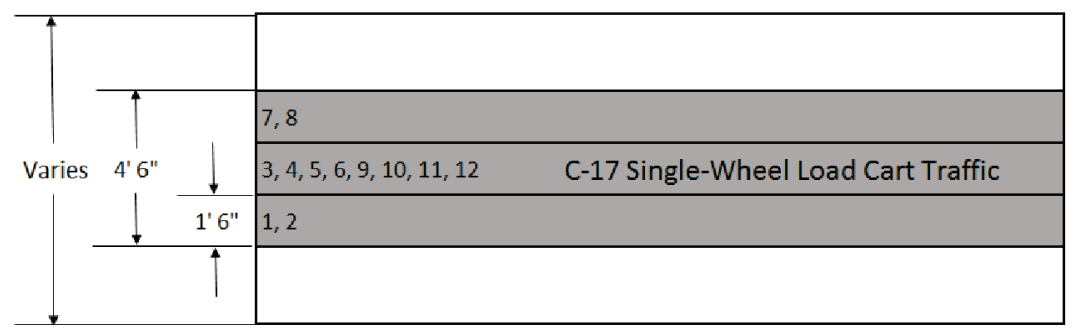

\subsubsection{F-15E load cart}

A specially designed single-wheel load cart was used to simulate F-15E aircraft traffic. The load cart was equipped with a 25 in. by 11 in. 18-ply tire inflated to $325 \mathrm{lb} /$ in. $^{2}$ and loaded such that the test wheel supported $26,750 \mathrm{lb}$, which simulated a standard gross load for an F-15E or F-22 at $63,900 \mathrm{lb}$. The maximum load for an $\mathrm{F}-15 \mathrm{E}$ is rated at $81,500 \mathrm{lb}$. A reduced load was chosen since the matting system was originally designed as a light-duty mat system. A simulated normally distributed traffic pattern was applied in a $3.75 \mathrm{ft}$ wide traffic area for the F-15E test item, as shown in Figure 13.

Figure 13. Single wheel F-15E traffic pattern.

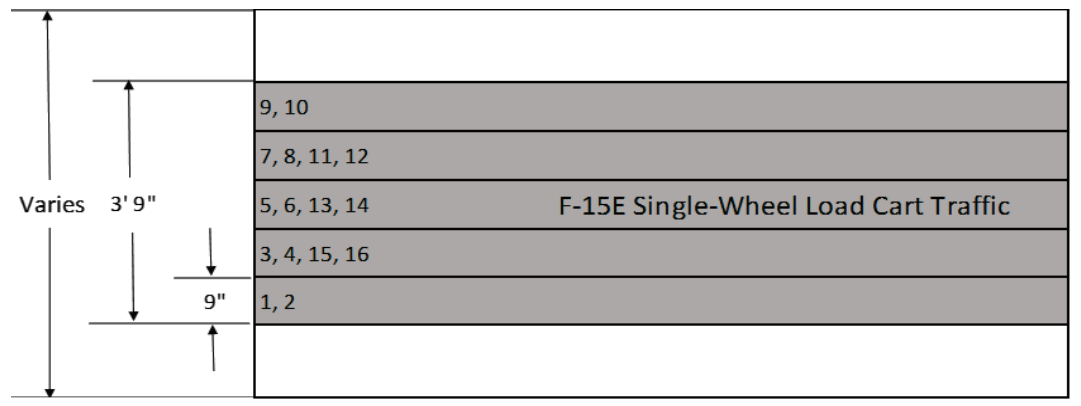

\subsection{Data collection}

A full suite of data was collected on the pretest subgrade, on the mat surface after mat placement, on the mat surface at specific intervals during trafficking, and on the posttest subgrade. Data collection intervals for the $\mathrm{C}-17$ and $\mathrm{F}-15 \mathrm{E}$ are shown in Tables 5 and 6, respectively. After the conclusion of trafficking, the mat panels were removed from the test section subgrade. During removal, each panel was inspected carefully to document any damage that was not observable from the surface. Damage was documented in detail by using notes and photos. Test section data collection locations are shown in Figure 11. 
Table 5. C-17 data collection intervals.

\begin{tabular}{|c|c|c|c|c|c|}
\hline \multirow[b]{2}{*}{ Total Passes } & \multirow[b]{2}{*}{$\begin{array}{l}\text { Centerline } \\
\text { Profile }\end{array}$} & \multicolumn{2}{|c|}{$\begin{array}{c}\text { Rut Depth (w/ Straight } \\
\text { Edge) }\end{array}$} & \multicolumn{2}{|c|}{ Cross Sections } \\
\hline & & Unloaded & $\begin{array}{l}\text { Loaded (w/ } \\
\text { Forklift \& } \\
\text { Blocks) }\end{array}$ & Unloaded & $\begin{array}{c}\text { Loaded (w/ } \\
\text { Forklift \& } \\
\text { Blocks) }\end{array}$ \\
\hline Pretest Subgrade & $x$ & $x$ & & $x$ & \\
\hline 0 & $x$ & $x$ & $x$ & $x$ & $x$ \\
\hline 12 & $x$ & $x$ & $x$ & $x$ & $x$ \\
\hline 36 & $x$ & $x$ & $x$ & $x$ & $x$ \\
\hline 72 & $x$ & $x$ & $x$ & $x$ & $x$ \\
\hline 120 & $x$ & $x$ & $x$ & $x$ & $x$ \\
\hline 240 & $x$ & $x$ & $x$ & $x$ & $x$ \\
\hline 480 & $x$ & $x$ & $x$ & $x$ & $x$ \\
\hline 840 & $x$ & $x$ & $x$ & $x$ & $x$ \\
\hline 1500 & $x$ & $x$ & $x$ & $x$ & $x$ \\
\hline $\begin{array}{l}\text { Posttest } \\
\text { Subgrade }\end{array}$ & $\mathrm{x}$ & $\mathrm{x}$ & & $\mathrm{X}$ & \\
\hline
\end{tabular}

Table 6. F-15E data collection intervals.

\begin{tabular}{|l|c|c|c|c|c|}
\hline \multirow{2}{*}{ Total Passes } & \multirow{2}{*}{$\begin{array}{c}\text { Centerline } \\
\text { Profile }\end{array}$} & Unloaded & $\begin{array}{c}\text { Rut Depth (w/ Straight Edge) } \\
\text { Forklift \& } \\
\text { Blocks) }\end{array}$ & \multicolumn{2}{|c|}{ Cross Sections } \\
\cline { 2 - 6 } Uretest Subgrade & $\mathrm{X}$ & $\mathrm{X}$ & & $\begin{array}{c}\text { Loaded (w/ } \\
\text { Forklift \& } \\
\text { Blocks) }\end{array}$ \\
\hline 0 & $\mathrm{X}$ & $\mathrm{X}$ & $\mathrm{X}$ & $\mathrm{X}$ & $\mathrm{X}$ \\
\hline 16 & $\mathrm{X}$ & $\mathrm{X}$ & $\mathrm{X}$ & $\mathrm{X}$ & $\mathrm{X}$ \\
\hline 48 & $\mathrm{X}$ & $\mathrm{X}$ & $\mathrm{X}$ & $\mathrm{X}$ & $\mathrm{X}$ \\
\hline 80 & $\mathrm{X}$ & $\mathrm{X}$ & $\mathrm{X}$ & $\mathrm{X}$ & $\mathrm{X}$ \\
\hline 128 & $\mathrm{X}$ & $\mathrm{X}$ & $\mathrm{X}$ & $\mathrm{X}$ & $\mathrm{X}$ \\
\hline 256 & $\mathrm{X}$ & $\mathrm{X}$ & $\mathrm{X}$ & $\mathrm{X}$ & $\mathrm{X}$ \\
\hline 496 & $\mathrm{X}$ & $\mathrm{X}$ & $\mathrm{X}$ & $\mathrm{X}$ & $\mathrm{X}$ \\
\hline 928 & $\mathrm{X}$ & $\mathrm{X}$ & $\mathrm{X}$ & $\mathrm{X}$ & $\mathrm{X}$ \\
\hline 1504 & $\mathrm{X}$ & $\mathrm{X}$ & $\mathrm{X}$ & $\mathrm{X}$ & $\mathrm{X}$ \\
\hline $\begin{array}{l}\text { Posttest } \\
\text { Subgrade }\end{array}$ & $\mathrm{X}$ & $\mathrm{X}$ & & $\mathrm{X}$ & \\
\hline
\end{tabular}


Data collection included

- Robotic total station measurements along the centerline on both the subgrade and the mat surface,

- Robotic total station measurements along cross sections on both the loaded and the unloaded mat surface and on the subgrade surface,

- Rut-depth measurements at the cross sections on both the loaded and the unloaded mat surface and on the subgrade surface, and

- Inspection of mats during trafficking and after the tests.

\subsection{Failure criteria}

Failure criteria were established based on U.S. Air Force requirements as well as previous testing experience with airfield matting. Failure criteria data were recorded and monitored for compliance.

\subsubsection{Mat breakage}

The system must be capable of supporting 1,500 passes of $\mathrm{C}-17$ or 1,500 passes of $\mathrm{F}-15 \mathrm{E}$ aircraft loads with less than $10 \%$ mat component failure (Rushing and Tingle 2007). Mat breakage percentages were calculated by dividing the area of the failed panel by the total area affected by the main landing gear. In both test items, the total area of matting affected by the single-wheel landing gear was calculated to be $319.6 \mathrm{ft}^{2}$. The test item area was calculated using the measured area after assembly. The measured dimensions of each test item were $18.8 \mathrm{ft}$ long and $25.25 \mathrm{ft}$ wide. Additionally, each Modified Light-Duty AM2 full panel measured $14.88 \mathrm{ft}^{2}$. In order for the $10 \%$ damage criterion to be reached, the area of the failed panels must exceed $32.0 \mathrm{ft}^{2}$; therefore, three full panels or two full panels and one half panel would have to fail in order to exceed the mat breakage limit for either the $\mathrm{C}-17$ or the $\mathrm{F}-15 \mathrm{E}$ test item.

Individual panels were considered failed if damage posed a significant tire hazard or caused instability of the load cart. Tire hazards were defined as damage that could not be reasonably maintained by simple field maintenance procedures. A typical example would be a top skin tear in excess of 10 in. that represents significant structural damage to the surface skin with sharp edges that may endanger an aircraft tire. 


\subsubsection{Permanent deformation}

Maximum mat surface deformation under aircraft load must not exceed 3.0 in. for the $\mathrm{C}-17$ or $1.25 \mathrm{in}$. for the $\mathrm{F}-15 \mathrm{E}$ at any time during trafficking. The permanent surface deformation limits were determined so that the gear loads of each respective aircraft did not exceed $80 \%$ of their maximum load capacity due to abrupt changes in ground elevation. Failure by permanent surface deformation was determined from robotic total station elevation measurements of cross sections and centerline profiles. Each of the following data collection categories was analyzed for compliance with the failure criterion.

- Centerline profile deformation,

- Unloaded surface deformation, and

- Loaded surface deformation. 


\section{Test Results}

\subsection{Mat breakage}

The following sections describe all mat breakage and the behavior of the Modified Light-Duty AM2 airfield mat under contingency C-17 and reduced F-15E load cart traffic.

\subsubsection{C-17 test item}

Trafficking of the $\mathrm{C}-17$ test item began 10 February 2017. The first damage noted on the Modified Light-Duty AM2 surface was at pass 240. Panels $\mathrm{C}_{5}, \mathrm{C} 6, \mathrm{C} 12, \mathrm{C} 13, \mathrm{C} 33$, and $\mathrm{C}_{34}$ all displayed short (1 in. or less) cracks originating from the corner fusion weld along the overlap/underlap connector and traveled along the friction stir weld on the top skin, as shown in Figure 14.

Figure 14. Corner crack in panel C13 at pass 240.

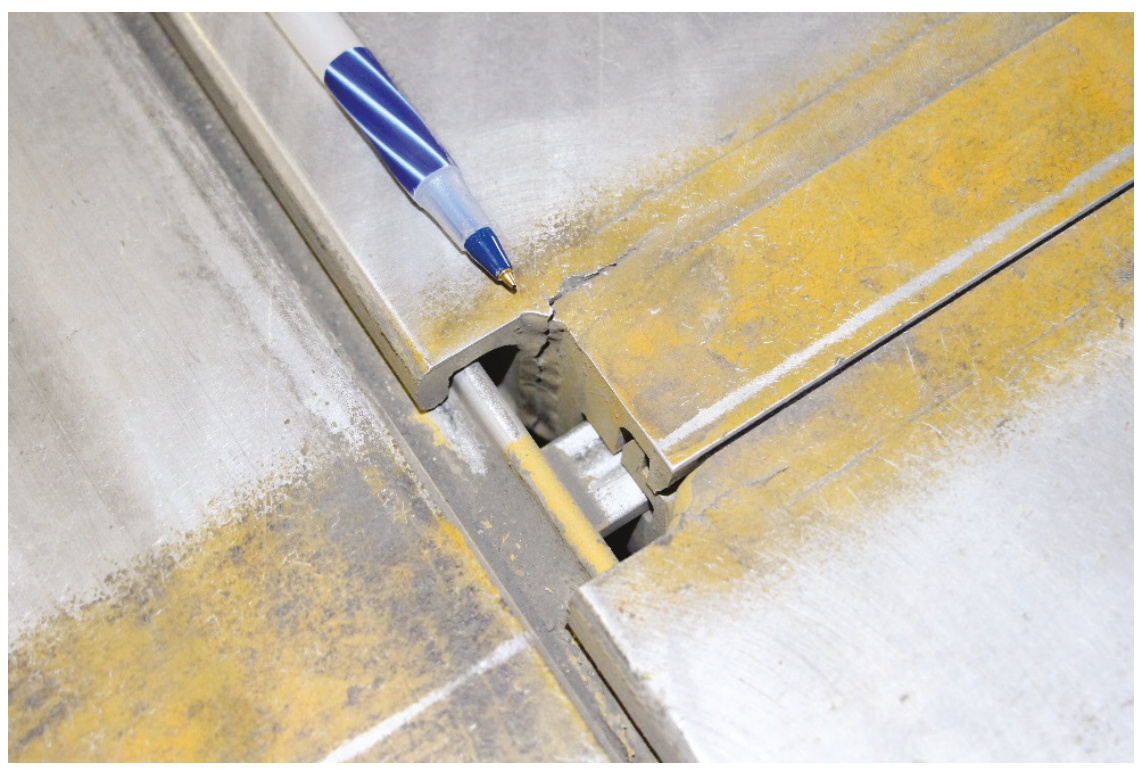

At pass 480 , the cracks in panels $\mathrm{C}_{5}, \mathrm{C} 6, \mathrm{C}_{12}, \mathrm{C}_{13}, \mathrm{C}_{33}$, and $\mathrm{C}_{34}$ continued to propagate along the friction stir weld on the top skin. Panels C20, C27, and $\mathrm{C} 28$ also developed the same cracks along the friction stir weld. Panel $\mathrm{C}_{33}$ had the longest crack of all the panels, measuring 6 in. Figure 15 reveals where the top skin began to tear away from the end of the vertical stiffeners on panel $\mathrm{C}_{33}$. 
Figure 15. Weld crack and top skin tears in panel C33 after 480 passes.

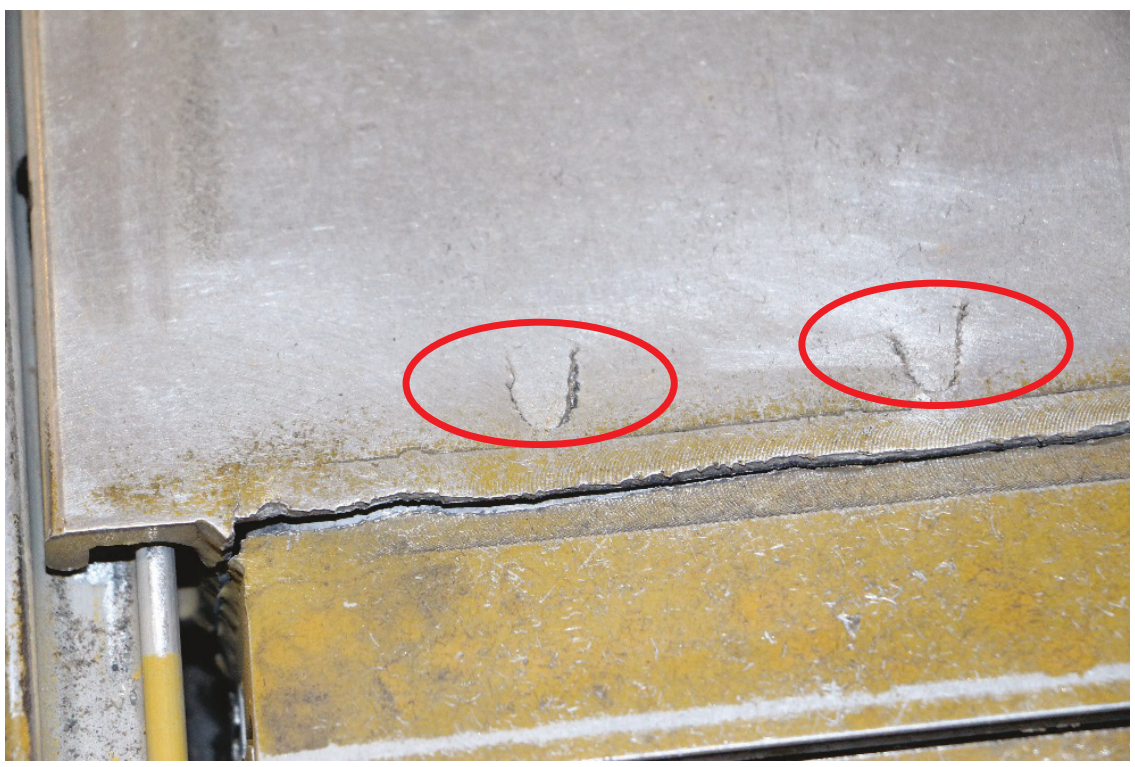

Traffic was stopped at pass 660 after the crack in the friction stir weld in panels $\mathrm{C}_{5}, \mathrm{C} 27$, and $\mathrm{C}_{33}$ had propagated along the full length of the overlap/underlap connector and detached the connector from the core of the panel; therefore, each of these panels were considered failed. Additionally, the top skin tore around the end of each vertical stiffener as well as along the female hinge connector of panel $\mathrm{C}_{33}$. Figure 16 is a photograph of the damage to panel $\mathrm{C}_{33}$. New damage was recorded in the form of a 3 in. top skin tear along the female hinge connector for panel C6.

Figure 16. Overlap/underlap connector damage on panel C33 after 660 passes.

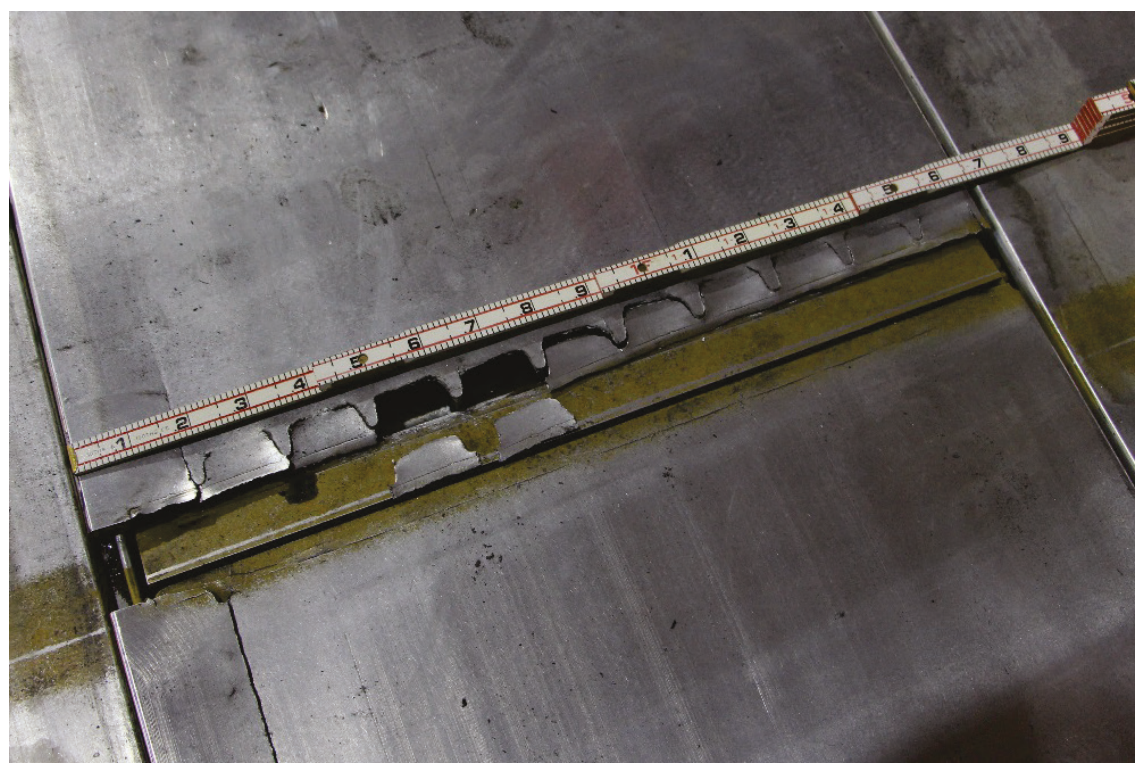


The area of the three damaged panels was $14.0 \%$ of the trafficked area, exceeding the $10 \%$ mat breakage damage criterion; therefore, the $\mathrm{C}-17$ test item was considered failed. Traffic was stopped at the next scheduled data interval of 768 passes to record final survey data. At pass 768 , a fourth panel had failed due to breakage in the same manner as the first three. Table 7 provides a summary of the mat breakage within the $\mathrm{C}-17$ test item.

Table 7. C-17 test item damage summary.

\begin{tabular}{|l|l|l|c|c|}
\hline $\begin{array}{l}\text { Pass } \\
\text { Number }\end{array}$ & Panel Number & Description of Damage & $\begin{array}{c}\text { Cumulative Failed } \\
\text { Panels }\end{array}$ & $\begin{array}{c}\text { Cumulative Mat } \\
\text { Breakage \% }\end{array}$ \\
\hline 240 & $\begin{array}{l}\text { C5, C6, C12, C13, } \\
\text { C33, C34 }\end{array}$ & $\begin{array}{l}\text { Overlap/underlap connector } \\
\text { weld crack }\end{array}$ & - & - \\
\hline \multirow{4}{*}{480} & $\begin{array}{l}\text { C5, C6, C12, C13, } \\
\text { C20, C27, C28, C33, } \\
\text { C34 }\end{array}$ & $\begin{array}{l}\text { Overlap/underlap connector } \\
\text { weld crack }\end{array}$ & - & - \\
\cline { 2 - 5 } & C33 & $\begin{array}{l}\text { Top skin tear around end of } \\
\text { vertical stiffeners }\end{array}$ & - & - \\
\hline \multirow{4}{*}{660} & C6, C33, C34 & $\begin{array}{l}\text { Top skin tear along female } \\
\text { hinge connector }\end{array}$ & - & - \\
\cline { 2 - 5 } & $\begin{array}{l}\text { C6, C12, C13, C20, } \\
\text { C26, C34 }\end{array}$ & $\begin{array}{l}\text { Overlap/underlap connector } \\
\text { weld crack }\end{array}$ & - & - \\
\cline { 2 - 5 } & C5, C27, C33 & $\begin{array}{l}\text { Full separation of } \\
\text { overlap/underlap connector }\end{array}$ & - & - \\
\hline
\end{tabular}

\subsubsection{F-15E test item}

Trafficking of the F-15E test item began on 14 February 2017. The first damage recorded was at pass 48. Panels F5, F6, F12, F13, F19, F20, F26, F27, F33, and F34 were all beginning to tear the top skin around the end of the vertical stiffeners beside the overlap/underlap connector. A photograph of the damage to panel F6 is shown in Figure 17.

After 80 passes, the vertical stiffener cracks in panels F5, F6, F12, F13, F19, F20, F26, F27, F33, and F34 had grown slightly, mainly because the core of the mats had plastically deformed while the overlap/underlap connectors had not (Figure 18). In addition to this damage, panel F2o had developed a crack in the fusion weld on the side between the overlap/underlap connector and the female hinge connector. 
Figure 17. Top skin tears on panel F6 at pass 48.

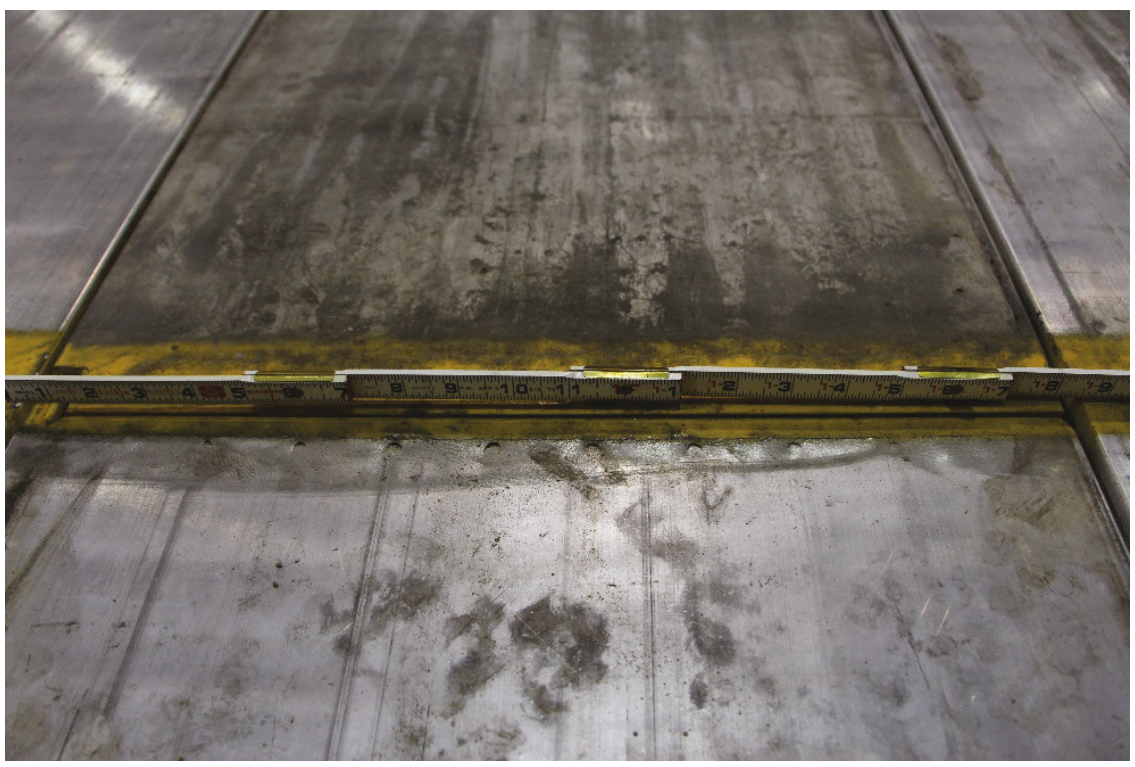

Figure 18. Top skin tears and deformation along the centerline at pass 80 .
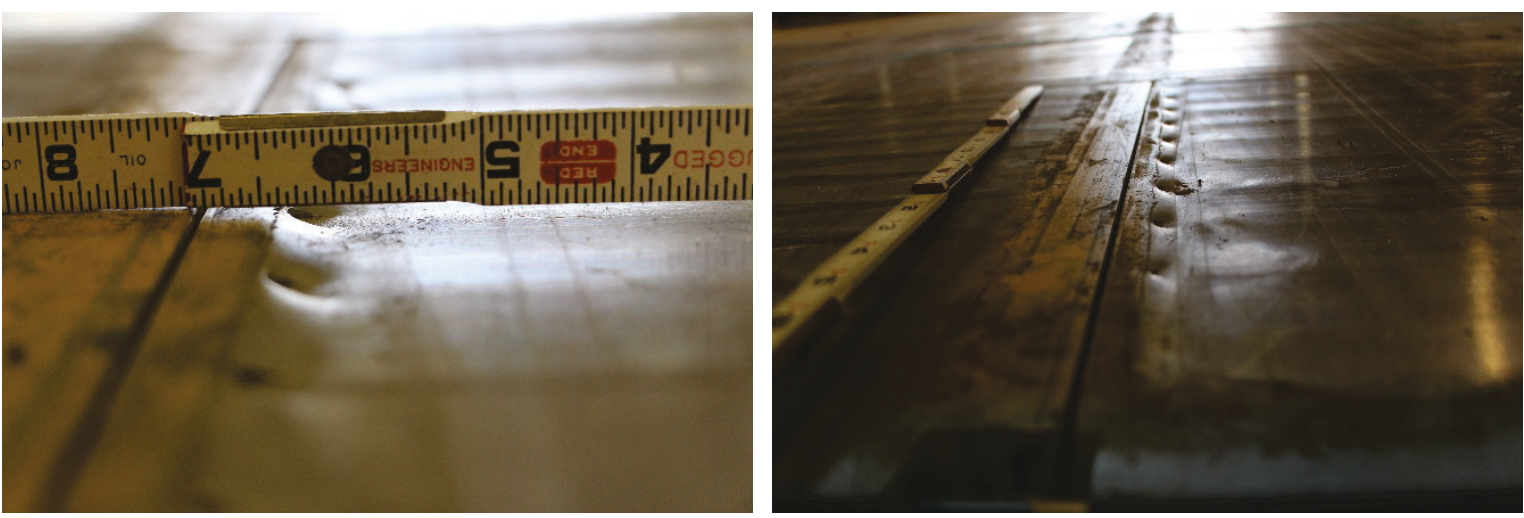

At the 128 pass interval, the vertical stiffener cracks in panels F5, F6, F12, F13, F19, F2O, F26, F27, F33, and F34 had continued to propagate due to deformation. Additionally, panels F6, F13, and F20 all revealed corner cracks in the fusion weld between the overlap/underlap connector and the female hinge connector. Figure 19 is a photograph of the two types of damage.

After 152 passes, traffic was ceased due to panel failures. Panels F6, F33, and F34 were all considered failed due to tire hazards. The overlap/ underlap connector sheared almost completely off from the mat core along the friction stir weld on the top skin on panels F33 and F34, while it sheared completely off on panel F6, as shown in Figure 20. The only other new damage recorded was a crack in the fusion weld between the overlap/ underlap connector and the female hinge connector of panel F2O. 
Figure 19. Top skin tears (left) and corner cracks (right) along centerline at pass 128.
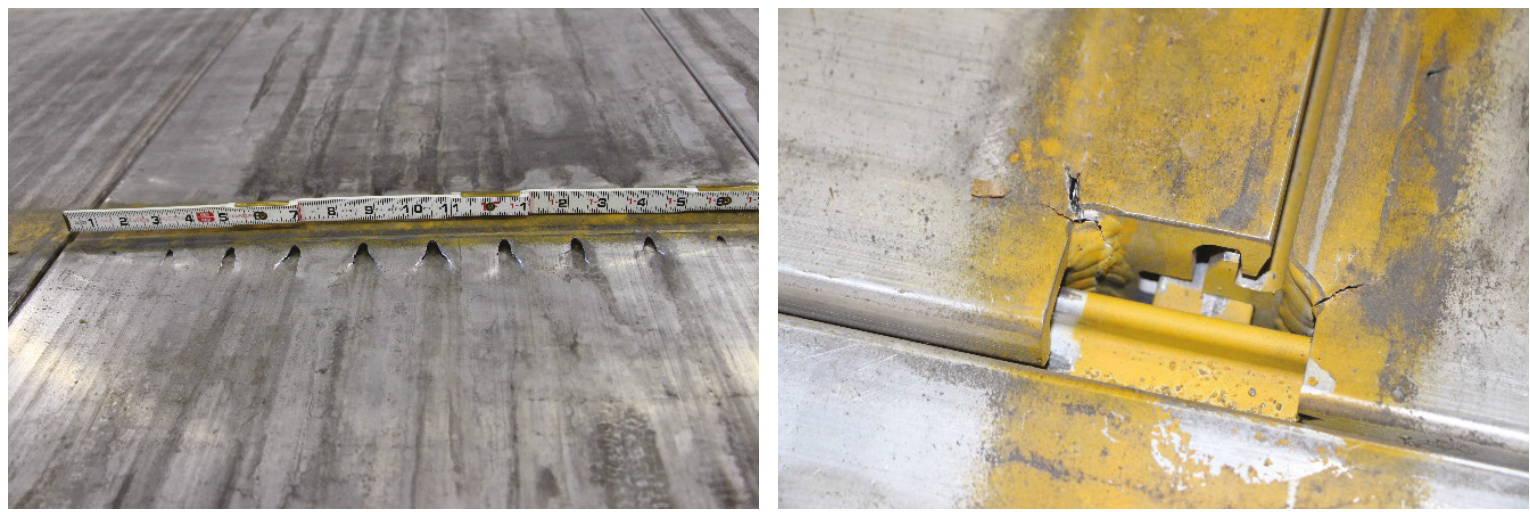

Figure 20. Weld crack and skin tears on panel F6 after 152 passes.
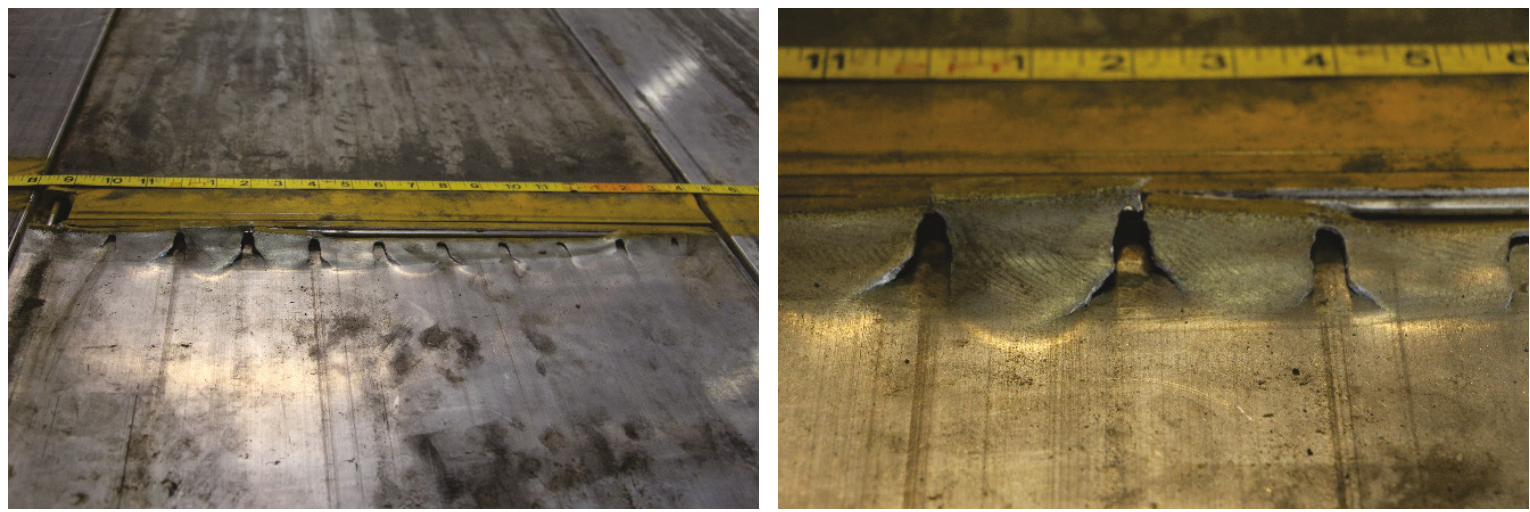

With three failed panels, the total mat breakage percent was $14.0 \%$ of the trafficked area, exceeding the $10 \%$ failure criterion; therefore, the $\mathrm{F}-15 \mathrm{E}$ traffic was ceased. Table 8 provides a summary of the mat breakage within the F-15E test item.

Table 8. F-15E test item damage summary.

\begin{tabular}{|c|c|c|c|c|}
\hline $\begin{array}{l}\text { Pass } \\
\text { Number }\end{array}$ & Panel Number & Description of Damage & $\begin{array}{c}\text { Cumulative Failed } \\
\text { Panels }\end{array}$ & $\begin{array}{c}\text { Cumulative Ma } \\
\text { Breakage } \%\end{array}$ \\
\hline 48 & $\begin{array}{l}\text { F5, F6, F12, F13, } \\
\text { F19, F20, F26, F27, } \\
\text { F33, F34 }\end{array}$ & $\begin{array}{l}\text { Top skin tear around end of } \\
\text { vertical stiffeners }\end{array}$ & - & - \\
\hline \multirow[t]{2}{*}{80} & $\begin{array}{l}\text { F5, F6, F12, F13, } \\
\text { F19, F20, F26, F27, } \\
\text { F33, F34 }\end{array}$ & $\begin{array}{l}\text { Top skin tear around end of } \\
\text { vertical stiffeners }\end{array}$ & - & - \\
\hline & $\mathrm{F} 20$ & $\begin{array}{l}\text { Overlap/underlap connector } \\
\text { weld crack }\end{array}$ & - & - \\
\hline \multirow[t]{2}{*}{128} & $\begin{array}{l}\text { F5, F6, F12, F13, } \\
\text { F19, F20, F26, F27, } \\
\text { F33, F34 }\end{array}$ & $\begin{array}{l}\text { Top skin tear around end of } \\
\text { vertical stiffeners }\end{array}$ & - & - \\
\hline & $\begin{array}{l}\text { F6, F13, F20, F33, } \\
\text { F34 }\end{array}$ & $\begin{array}{l}\text { Overlap/underlap connector } \\
\text { weld crack }\end{array}$ & - & - \\
\hline
\end{tabular}




\begin{tabular}{|l|l|l|c|c|}
\hline $\begin{array}{l}\text { Pass } \\
\text { Number }\end{array}$ & Panel Number & Description of Damage & $\begin{array}{c}\text { Cumulative Failed } \\
\text { Panels }\end{array}$ & $\begin{array}{c}\text { Cumulative Mat } \\
\text { Breakage } \%\end{array}$ \\
\hline \multirow{3}{*}{152} & $\begin{array}{l}\text { F5, F12, F13, F19, } \\
\text { F20, F26, F27 }\end{array}$ & $\begin{array}{l}\text { Top skin tear around end of } \\
\text { vertical stiffeners }\end{array}$ & - & - \\
\cline { 2 - 5 } & F13, F19, F20, & $\begin{array}{l}\text { Overlap/underlap connector } \\
\text { weld crack }\end{array}$ & - & - \\
\cline { 2 - 5 } & F6, F33, F34 & $\begin{array}{l}\text { Full separation of } \\
\text { overlap/underlap connector }\end{array}$ & 3 & 13.6 \\
\hline
\end{tabular}

\subsection{Permanent deformation}

The following sections describe the permanent deformation measured on the subgrade as well as on the mat surface of the Modified Light-Duty AM2 airfield mat under contingency $\mathrm{C}-17$ and reduced $\mathrm{F}-15 \mathrm{E}$ load cart traffic.

\subsubsection{C-17 test item}

A plot of the centerline profile at different pass levels on the mat surface, as determined from robotic total station recordings, for the $\mathrm{C}-17$ test item is shown in Figure 21. All of the deformation values were below the 3.0 in. failure criterion.

Figure 21. C-17 centerline profile elevations.

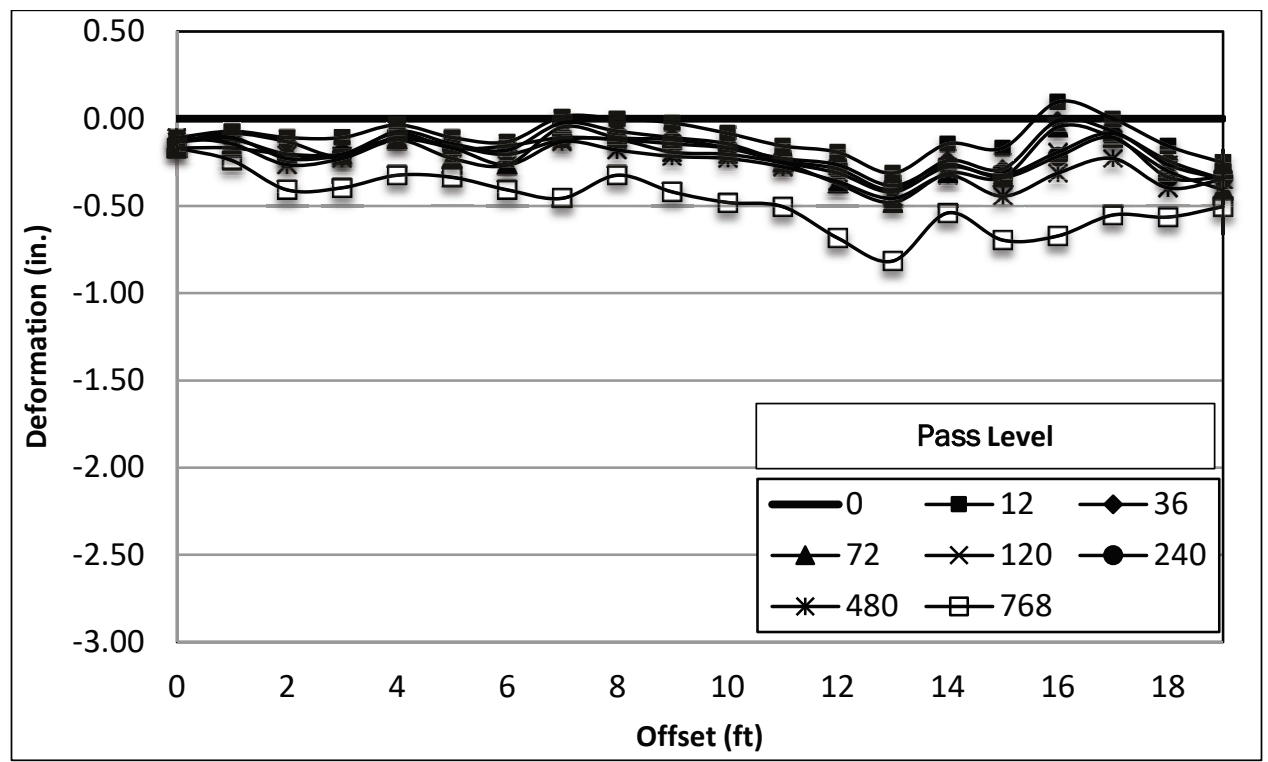

A plot of the subgrade centerline profile for the $\mathrm{C}-17$ test section is shown in Figure 22. While the change in elevation values were approaching 3.0 in., the deformation values were all below $0.5 \mathrm{in}$. 
Figure 22. C-17 subgrade centerline profile elevations.

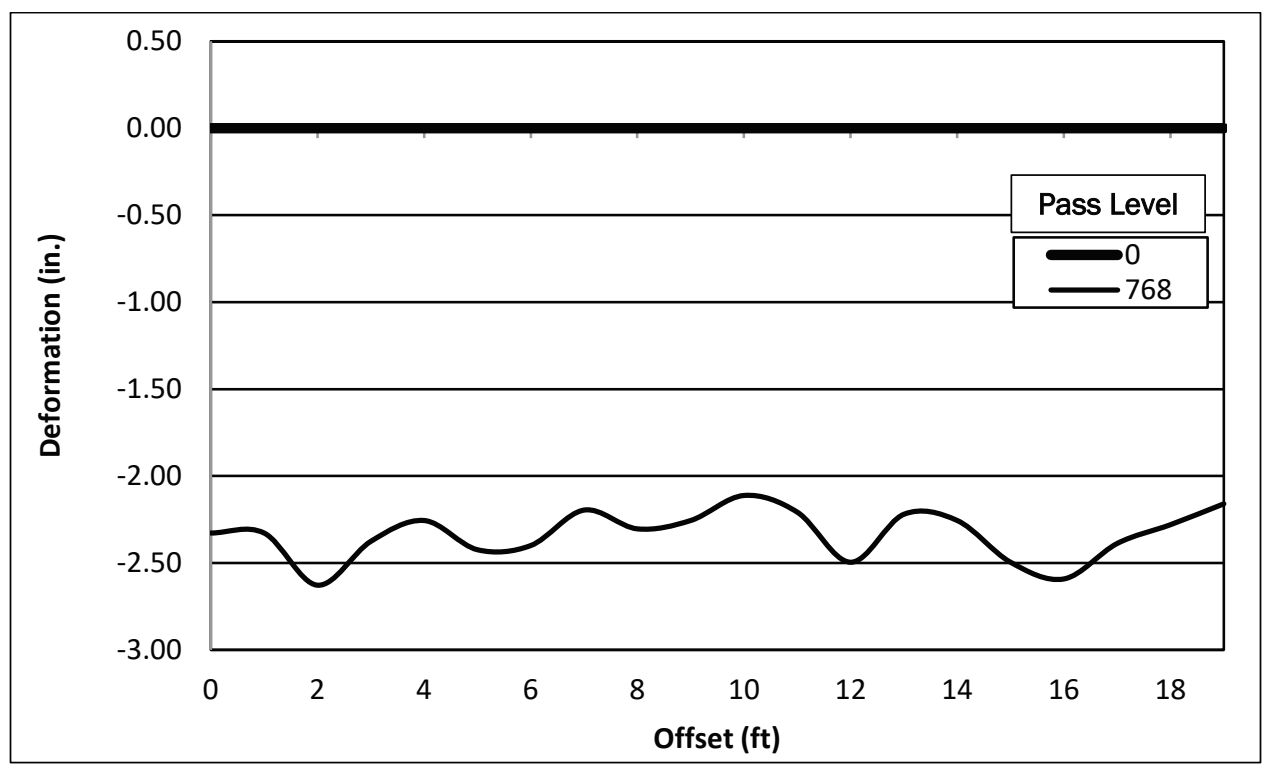

The elevations of the loaded, unloaded, and subgrade cross sections were collected along the three cross sections for the $\mathrm{C}-17$ test item. The deformation values of each of the three cross sections were averaged for each data set and displayed in Figures 23, 24, and 25, respectively. All of the crosssection permanent deformation values were below the 3.0 in. criterion.

Figure 23. C-17 loaded cross-section elevations.

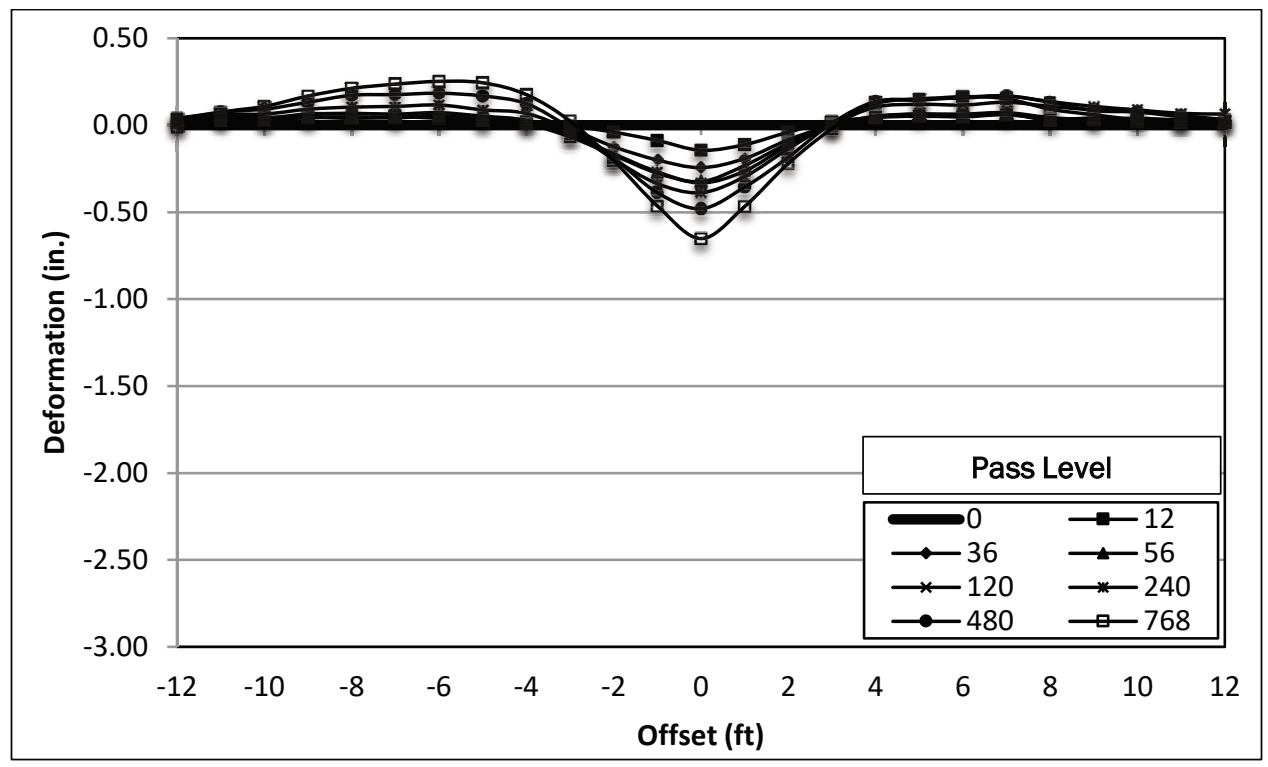


Figure 24. C-17 unloaded cross-section elevations.

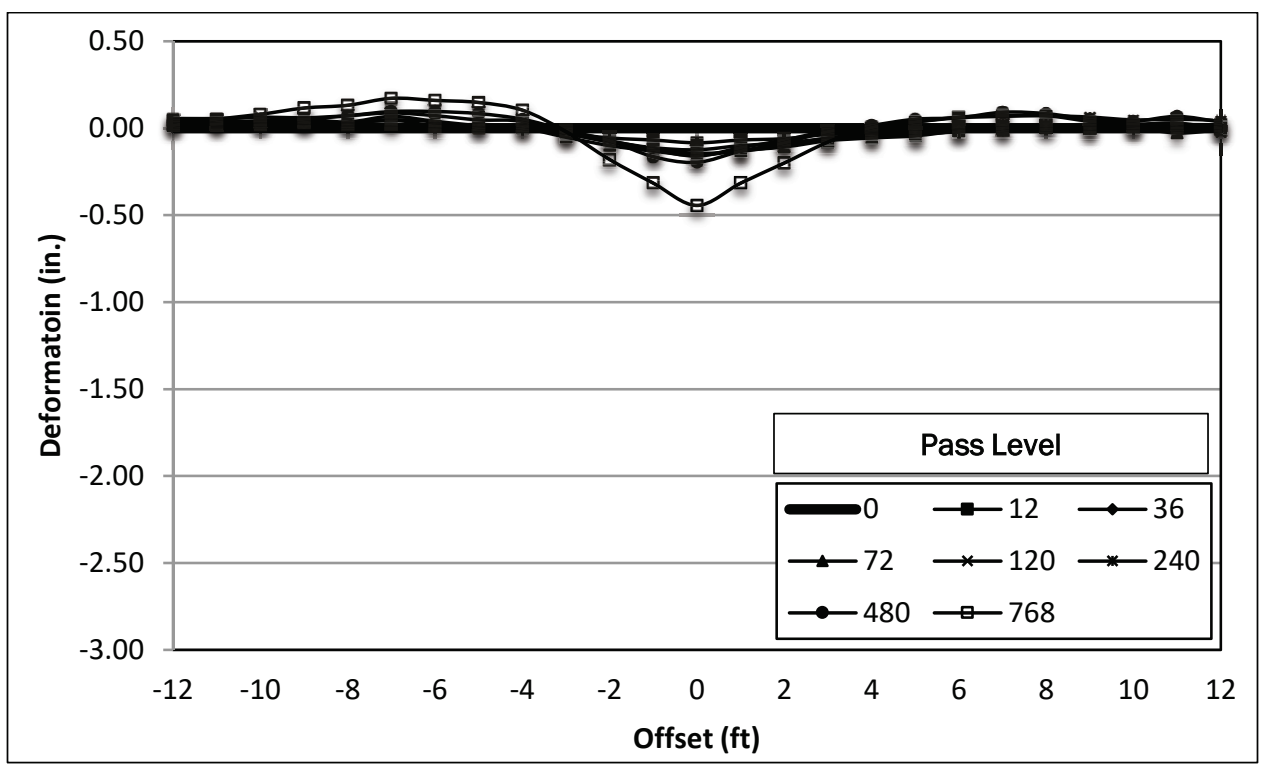

Figure 25. C-17 subgrade cross-section elevations.

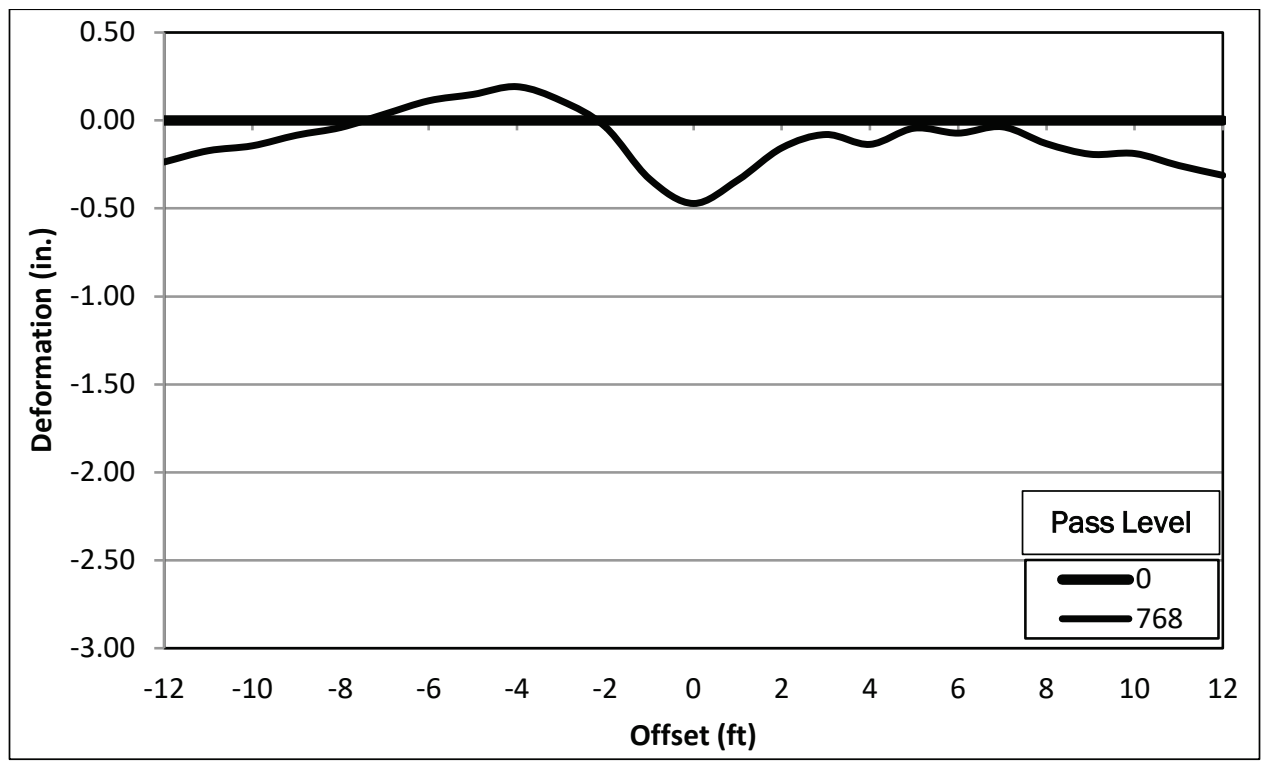

Figure 26 displays the average maximum permanent deformation data from the loaded and unloaded cross sections. Maximum deformation values were determined as the difference in elevation between the average heights of the elevated material on each side of the lowest point to the bottom of the trough. 
Figure 26. C-17 maximum deformation vs. pass level.

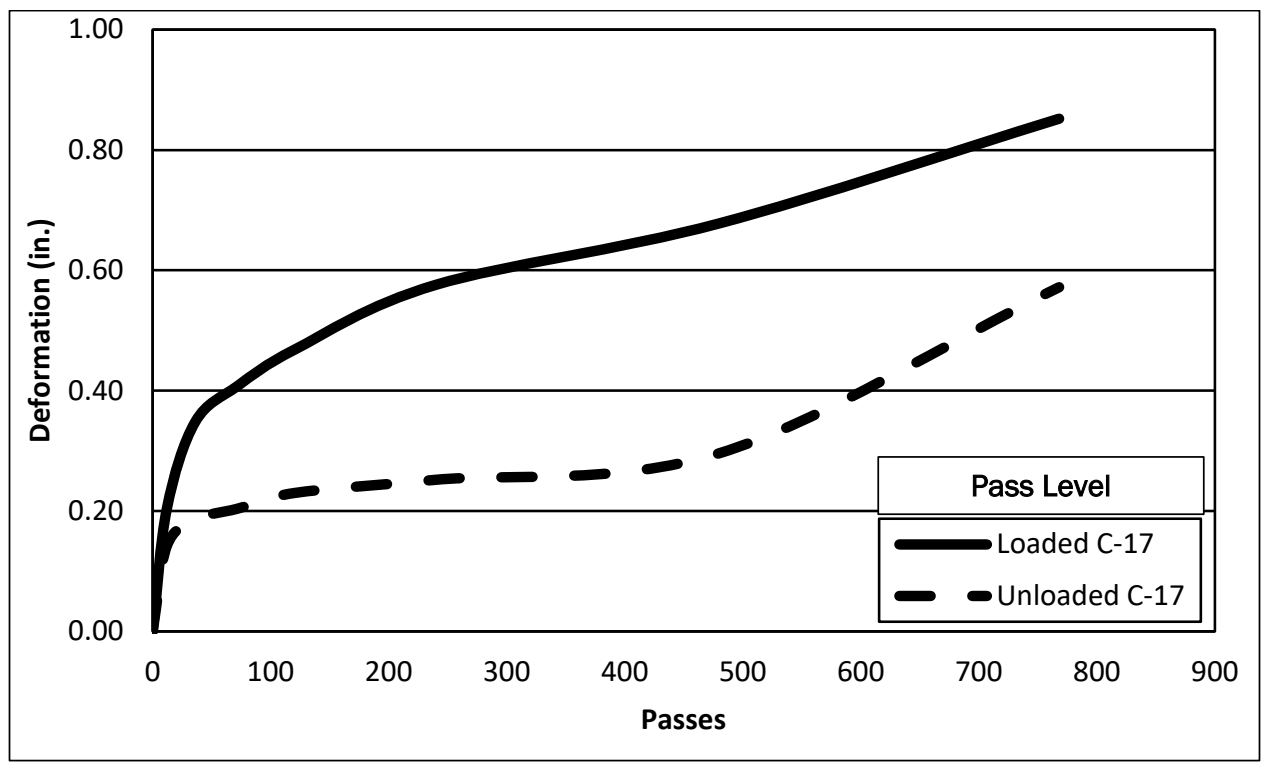

\subsubsection{F-15E test item}

A plot of the centerline profile on the mat surface, as determined from robotic total station recordings, for the $\mathrm{F}-15 \mathrm{E}$ test item is shown in Figure 27. None of the deformation values were above the $1.25 \mathrm{in}$. failure criterion.

A plot of the subgrade centerline profile for the F-15E test section is shown in Figure 28. None of the centerline profile deformation values exceed the failure criterion.

The loaded, unloaded, and subgrade cross-section elevations collected along the three cross sections for the F-15E test item were averaged and are displayed in Figures 29, 30, and 31, respectively. In Figure 31, the subgrade cross-section deformation measured 1.17 in., which was close to the failure criterion; however, it was still within the allowable limits.

Figure 32 displays the average maximum deformation data from the loaded and unloaded cross sections. Maximum deformation values were determined as the difference in elevation between the average heights of the elevated material on each side of the lowest point in the bottom of the trough. 
Figure 27. F-15E centerline profile elevations.

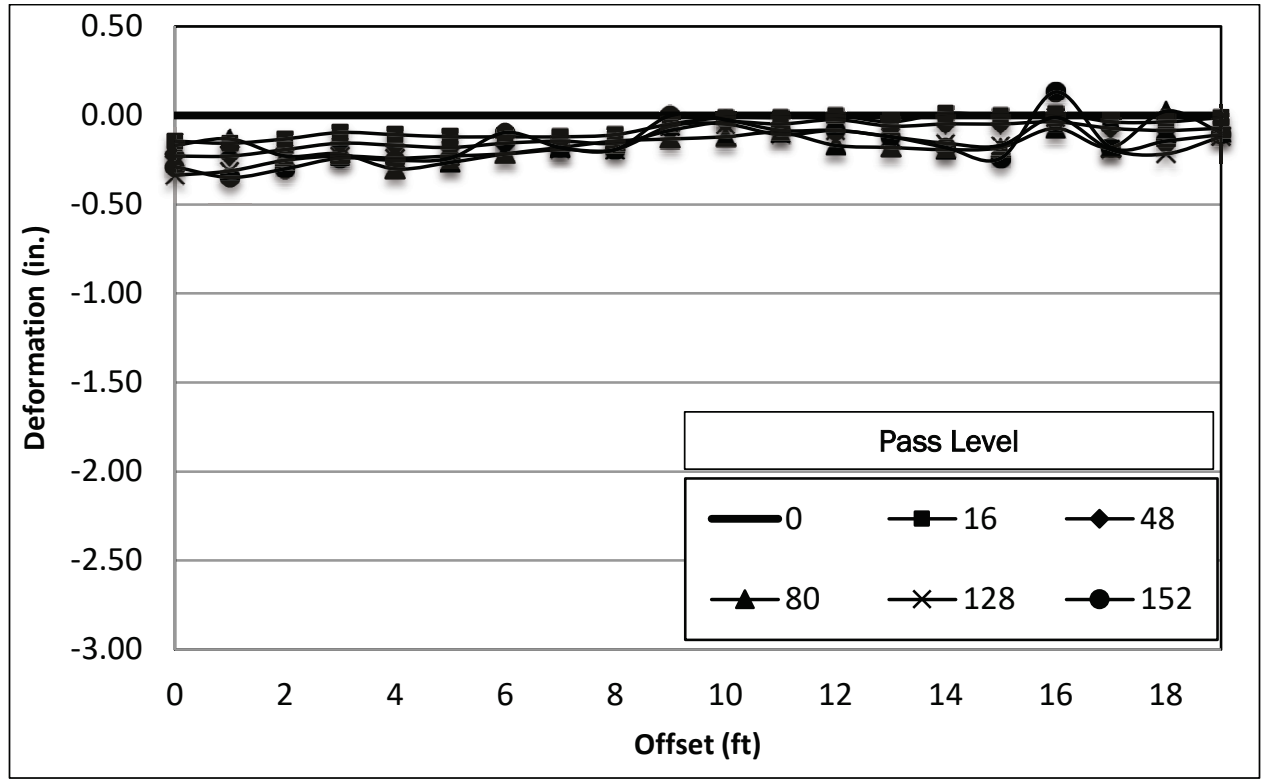

Figure 28. F-15E subgrade centerline profile elevations.

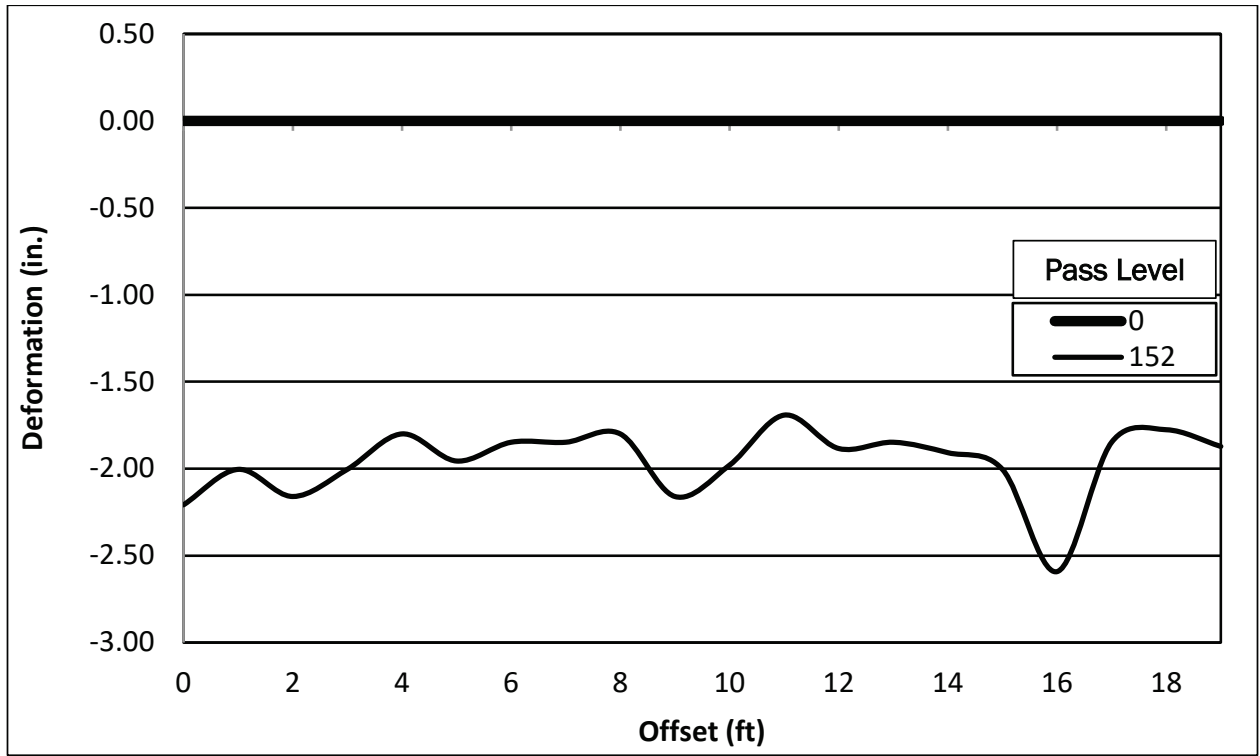


Figure 29. F-15E loaded cross-section elevations.

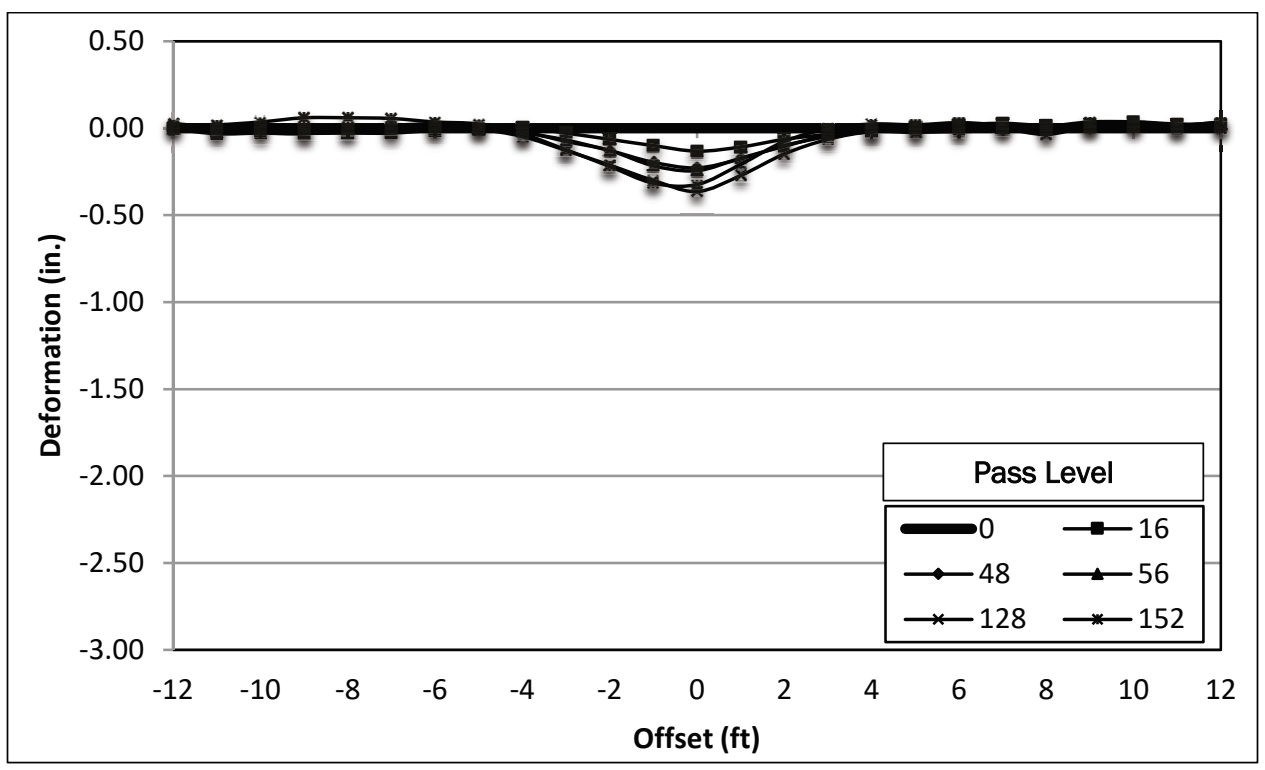

Figure 30. F-15E unloaded cross-section elevations.

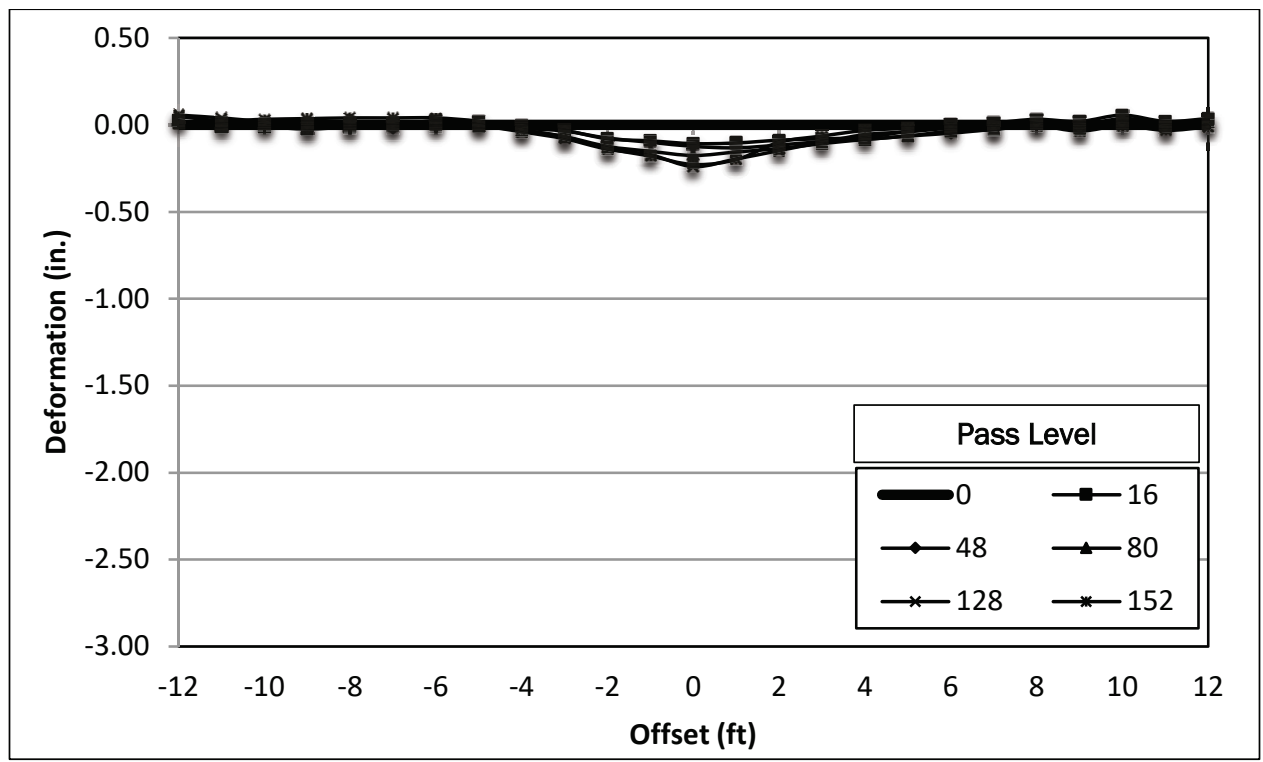


Figure 31. F-15E subgrade cross-section elevations.

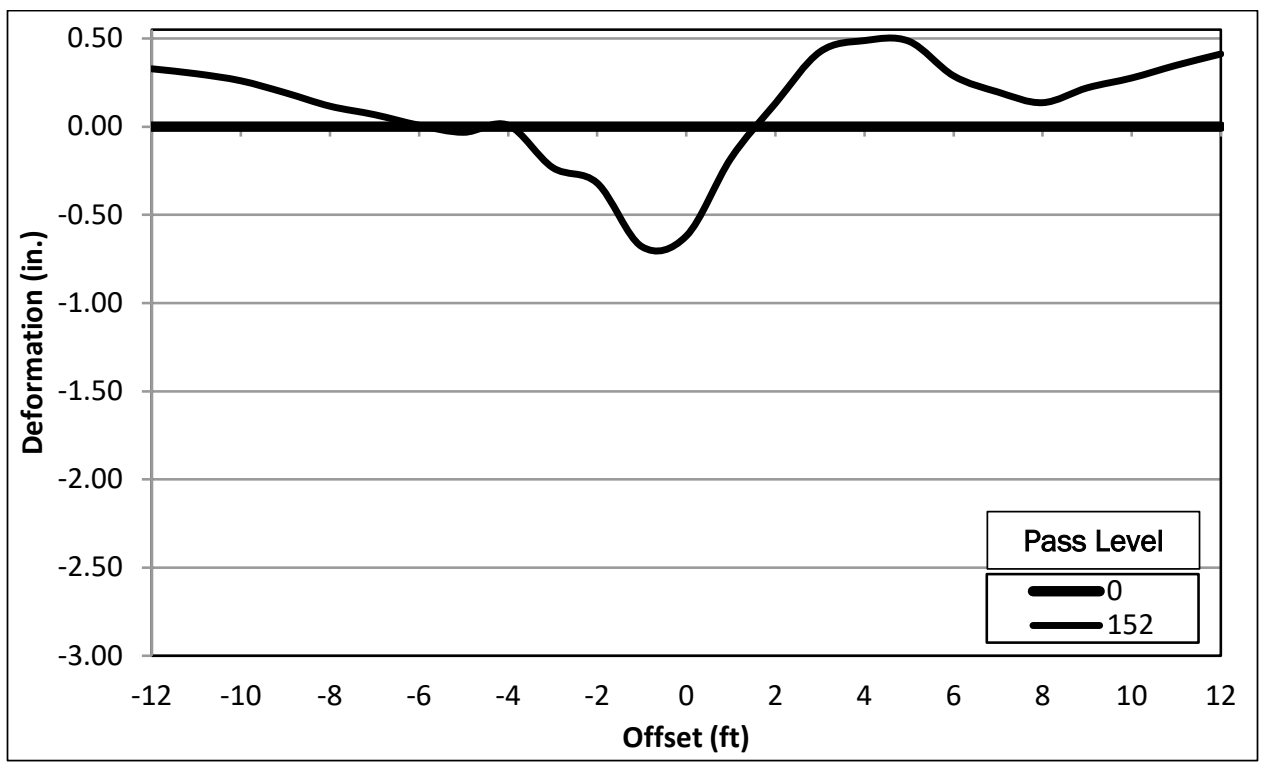

Figure 32. F-15E maximum deformation vs. pass level.

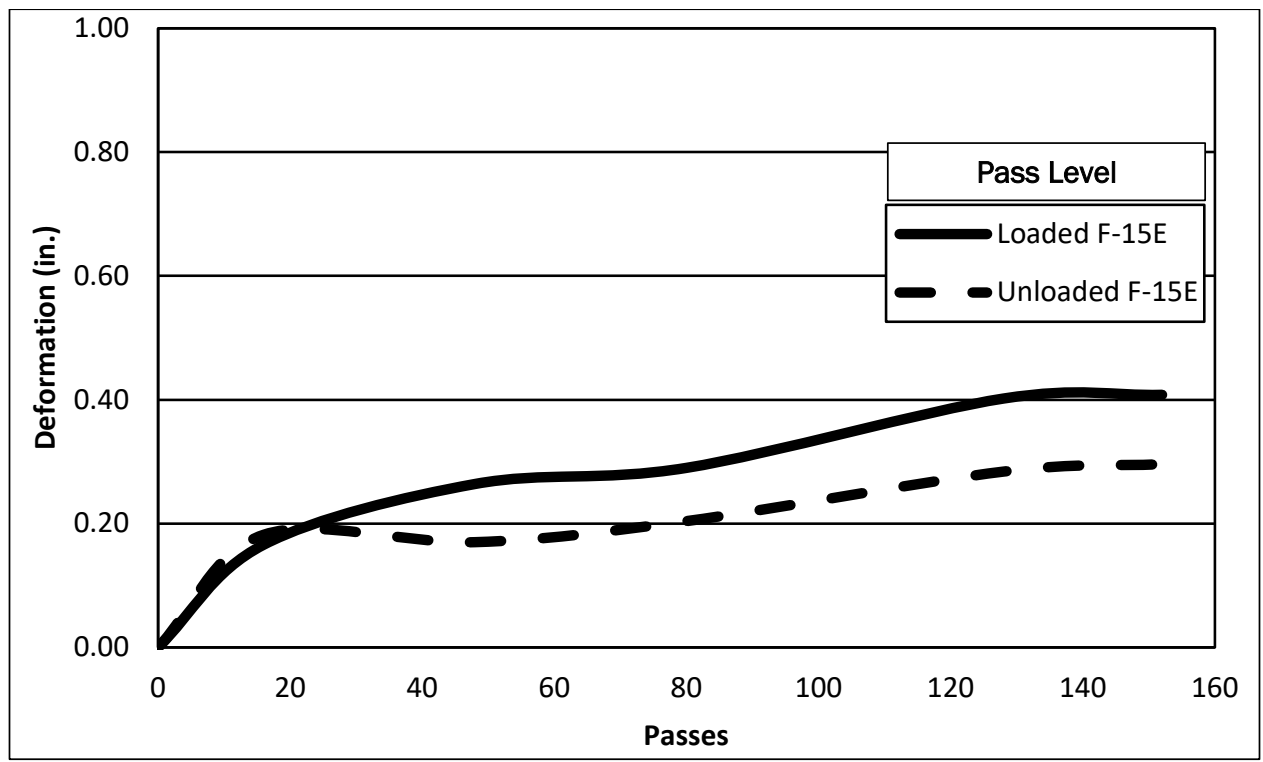




\section{Analysis of Results}

\subsection{Mat breakage}

The $\mathrm{C}-17$ test item sustained 660 passes of simulated traffic before failing due to mat breakage. The main failure mode was crack propagation in the weld between the overlap/underlap connector and the mat core along the centerline of the test item. The cracks began on the fusion weld between the overlap/underlap connector and the female hinge connector and then propagated up and along the friction stir weld. Upon removal of the trafficked C-17 panels, it was noted that the overlap/underlap connectors on panels $\mathrm{C}_{5}, \mathrm{C}_{2}$, and $\mathrm{C}_{33}$ were completely sheared off from the core of the mat, as shown in Figure 33. Additionally, after the weld cracks were recorded, a couple of the damaged panels revealed cracking around the end of the vertical stiffeners next to the overlap/underlap connector. Finally, three panels exhibited top skin tears along the female hinge connector. Panels C9, C16, C23, $\mathrm{C}_{30}$, and $\mathrm{C}_{37}$ all had large cracks in the center of the female hinge connector (Figure 34), which was documented upon removal. Panel C2 was the only center panel that did not exhibit a crack within the female hinge connector.

Figure 33. Complete separation of the overlap/underlap connector on panel C33.

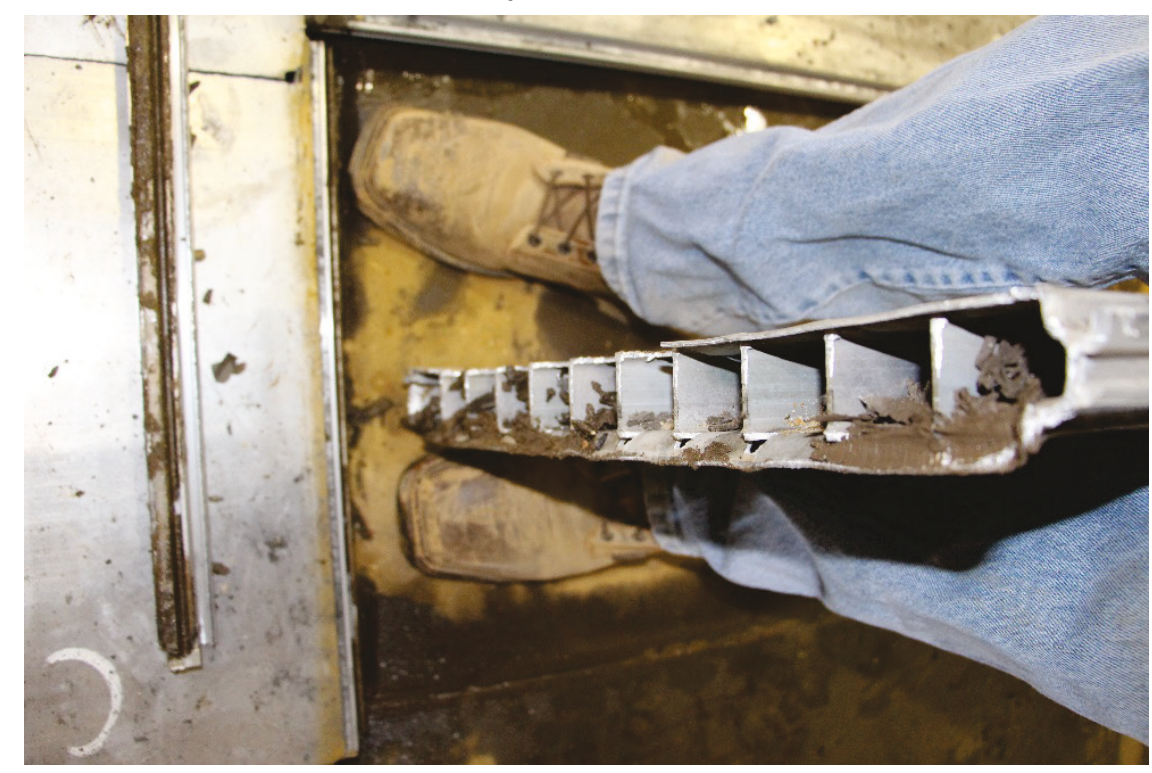


Figure 34. Female hinge connector crack in panel C37.

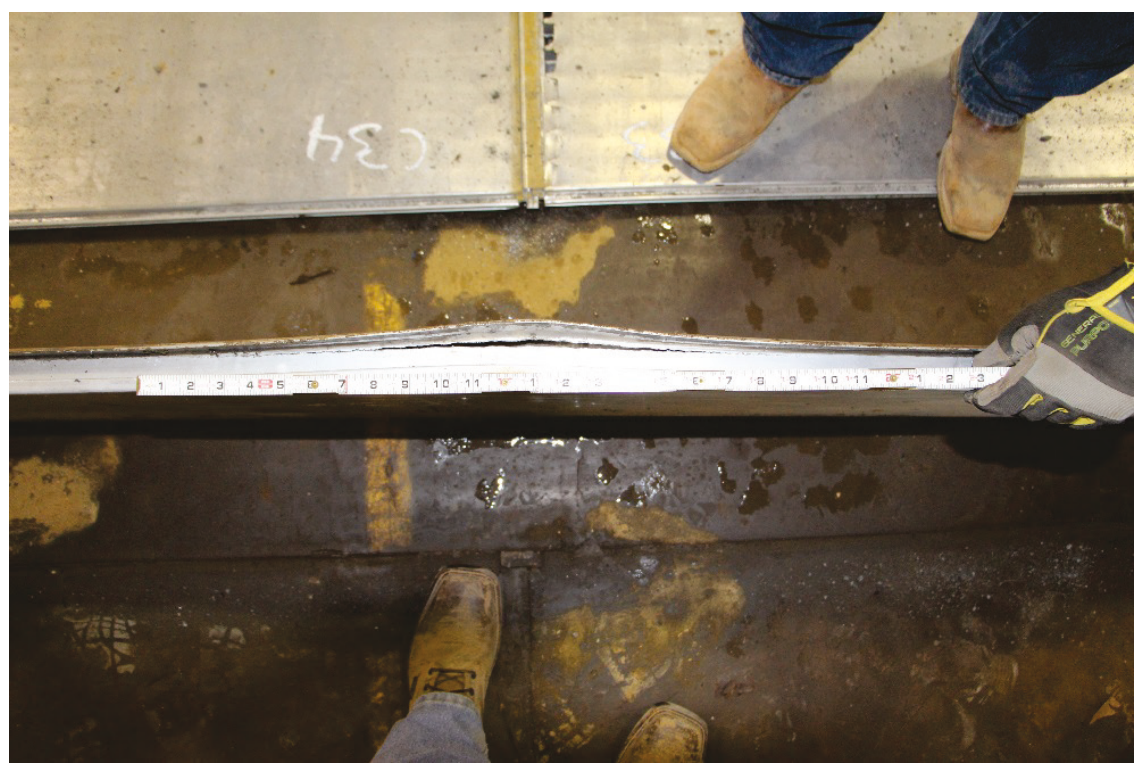

The $\mathrm{F}-15 \mathrm{E}$ test item sustained 128 passes of simulated traffic before failing due to mat breakage. The damaged panels showed failure modes similar to the $\mathrm{C}-17$ test item, yet the damage progressed more quickly mainly due to the higher surface stresses of the $\mathrm{F}-15 \mathrm{E}$ loading conditions. Unlike the $\mathrm{C}-17$ test item, the cracks were visible on the top skin around the end of the vertical stiffeners before the cracks in the overlap/underlap connector welds. Even so, panels F6, F33, and F34 all failed once the crack in the friction stir weld propagated the full length of the overlap/underlap connector. Even though the cracks had propagated the full length of the overlap/underlap connector, none of the connectors completely sheared off. In fact, all three of these connectors were still connected by the fusion weld between the overlap/underlap connector and the male hinge connector. The cracks usually began in the weld between the female hinge connector and the overlap/underlap connector because of the tensile stress applied to the female hinge connector by the male hinge connector during trafficking. Upon removing the trafficked F-15E panels, it was noted that every panel with an overlap/underlap joint along the centerline revealed a cracked friction stir weld on the bottom skin, which explained the deformation and cracks around the end of the vertical stiffeners on the top skin.

It was inferred that the overlap/underlap connector failures occurred because of the design for the connector's attachment to the core. A photograph and a sketch of the overlap/underlap connector design are shown in Figures 35 and 36, respectively. The small tabs (shown in red) give support for the friction stir weld; however, there is no additional 
support between the overlap/underlap connector and the core of the mat. With only the top and the bottom skins to transfer the load between the connector and the core, large amounts of plastic deformation occurred, and cracks propagated quickly through the welds. The Modified LightDuty AM2 connection was designed differently than AM2 in order to meet the $4.0 \mathrm{lb} / \mathrm{ft}^{2}$ weight requirement for RPA matting. If the connection between the overlap/underlap connector and the core were improved, the matting system would likely provide better performance; however, cracks in the female hinge connector would continue to be a concern.

Figure 35. Overlap/underlap connector separation.

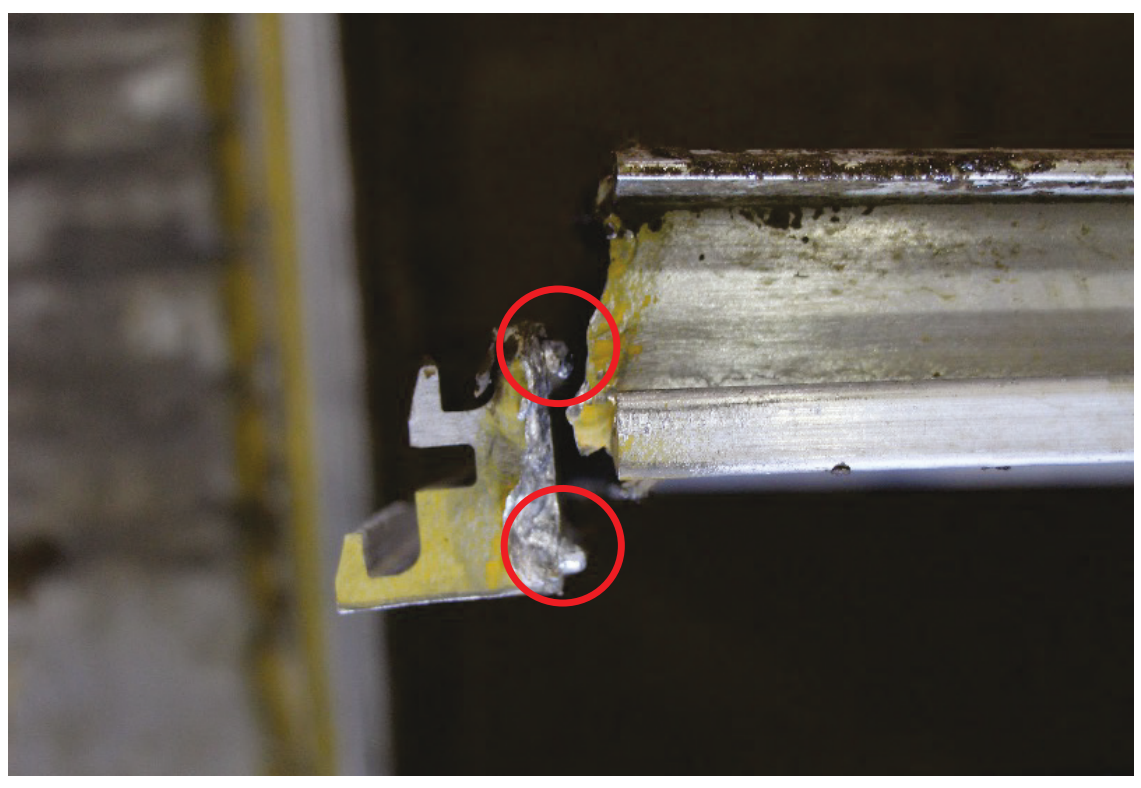

Figure 36. Sketch of the overlap/underlap connector's weld support tabs.

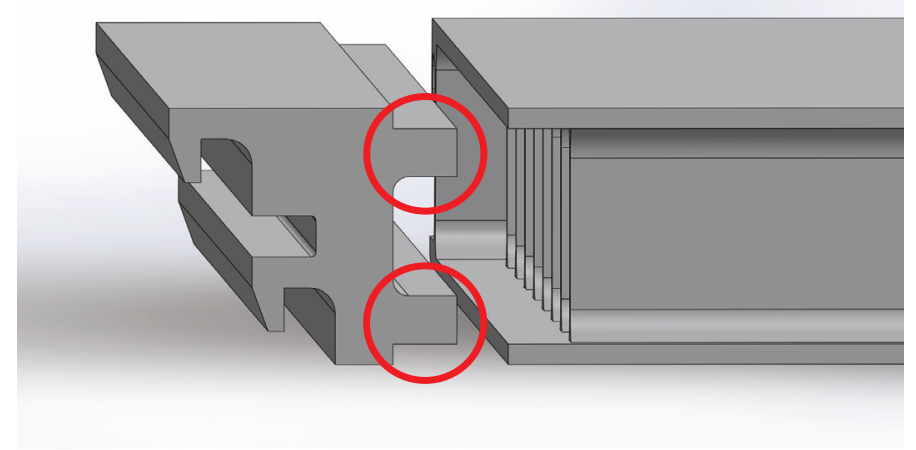




\subsection{Permanent deformation}

The $\mathrm{C}-17$ test item did not exceed the permanent deformation failure criterion of $3.0 \mathrm{in}$. in any type of measurement. The maximum deformation on top of the mat surface measured $0.85 \mathrm{in}$. at 768 passes. Following the trend from Figure 26, it is expected that the test item would not have reached 3 in. of permanent deformation by 1,500 passes if it had not failed by mat breakage beforehand. The limited amount of deformation showed that the Modified Light-Duty AM2 was globally stiff enough to support contingency $\mathrm{C}-17$ loads out to almost 800 passes, even with the accumulated mat damage.

The F-15E test item did not exceed the permanent deformation failure criterion of $1.25 \mathrm{in}$. in any type of measurement. The measured maximum deformation on the mat surface was 0.41 in. at 152 passes. The maximum deformation on the subgrade measured $1.17 \mathrm{in}$. Based on the trend in Figure 32 and the elevations shown in Figure 31, the F-15E test item would have failed by rutting before reaching the 1,500 pass requirement. One reason that the deformation was greater with respect to its failure requirement for the $\mathrm{F}-15 \mathrm{E}$ test item was that the overlap/underlap connectors sheared off quickly, causing the deformation directly under the centerline to grow more quickly than the overall mat system would typically allow. The core of the mat deformed less rapidly than the overlap/underlap connector.

If the connection between the overlap/underlap connector and the core were improved, the mat system would likely be able to prevent either the contingency $\mathrm{C}-17$ or the reduced $\mathrm{F}-15 \mathrm{E}$ loads from exceeding the permanent deformation criterion. 


\section{Conclusion and Recommendation}

\subsection{Conclusion}

Modified Light-Duty AM2 was evaluated with simulated contingency C-17 traffic and reduced F-15E traffic over a subgrade with a strength of $6 \mathrm{CBR}$. The results of the evaluation showed that the current design of the prototype matting system was incapable of sustaining 1,500 passes of contingency $\mathrm{C}-17$ or reduced $\mathrm{F}-15 \mathrm{E}$ traffic. Traffic was stopped due to more than $10 \%$ mat breakage in each of the test items.

Mat panel failures were all associated with the connection between the overlap/underlap connector and the core of the mat. It is believed that improvement of the connection design would drastically increase the performance of the system. Even so, it is still unclear as to whether 1,500 passes would be obtainable with contingency $\mathrm{C}-17$ or reduced $\mathrm{F}-15 \mathrm{E}$ traffic. In summary, improvements to the end connector design could increase the life of the mat and make it a viable option for a lighter-weight replacement for standard AM2.

\subsection{Recommendation}

Modified Light-Duty AM2 in its current design should not be used for contingency $\mathrm{C}-17$ or reduced $\mathrm{F}-15 \mathrm{E}$ traffic. It is recommended that the connection between the mat core and the overlap/underlap connectors be redesigned before further consideration of Modified Light-Duty AM2 as a lighter-weight replacement for standard AM2. Regardless, Modified LightDuty AM2 should be considered as a viable solution for RPA and similar traffic, such as vertical takeoff and landing (VTOL) operations. 


\section{References}

ASTM International. 2011. Standard practice for classification of soils for engineering purposes (USCS). Designation: D 2487. West Conshohocken, PA: ASTM International.

. 2007. Standard test method for CBR of laboratory compacted soils. Designation: D 1883. West Conshohocken, PA: ASTM International.

. 2015. Standard test methods for in-place density and water content of soils and soil aggregate by nuclear methods (shallow depth). Designation: D 6938. West Conshohocken, PA: ASTM International.

2010a. Standard test method for density of soil in place by the drive cylinder. Designation: D 2937. West Conshohocken, PA: ASTM International.

2012. Standard test method for laboratory compaction characteristics of soil using modified effort. Designation: D 1557. West Conshohocken, PA: ASTM International.

.2010b. Standard test methods for laboratory determination of water (moisture) content of soil and rock by mass. Designation: D 2216. West Conshohocken, PA: ASTM International.

. 2007b. Standard test method for particle size analysis of soils. Designation: D 422. West Conshohocken, PA: ASTM International.

2009. Standard test method for use of the dynamic cone penetrometer in shallow pavement applications. Designation: D 6951. West Conshohocken, PA: ASTM International.

2007c. Standard test methods for liquid limit, plastic limit, and plasticity index of soils. Designation: D 4318. West Conshohocken, PA: ASTM International.

Hoffman, N. R., L. Garcia, T. W. Rushing, J. B. Jordon, and P. G. Allison. 2017. Development and evaluation of modified light-duty AM2 airfield matting ERDC/GSL TR-18-8. Vicksburg, MS: U.S. Army Engineer Research and Development Center.

Rushing, T. W., L. Garcia, and Q. S. Mason. 2012. Evaluation of faun aluminum mat systems. ERDC/GSL TR-12-32. Vicksburg, MS: U.S. Army Engineer Research and Development Center.

Rushing, T. W., and J. S. Tingle. 2007. AM2 and M19 airfield mat evaluation for the rapid parking ramp expansion program. ERDC/GSL TR-07-5. Vicksburg, MS: U.S. Army Engineer Research and Development Center.

U.S. Army Corps of Engineers. 1995. Standard test method for California Bearing Ratio of soils in place. Designation: CRD-C654-95. Vicksburg, MS: Waterways Experiment Station 


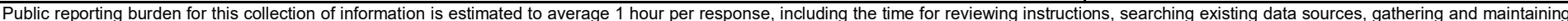

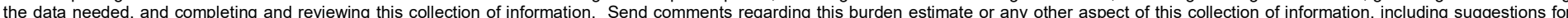

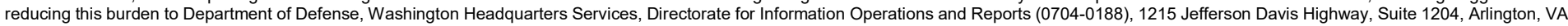

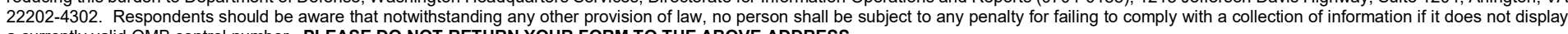
a currently valid OMB control number. PLEASE DO NOT RETURN YOUR FORM TO THE ABOVE ADDRESS.
1. REPORT DATE (DD-MM-YYYY) 2. REPORT TYPE
3. DATES COVERED (From - To)

June 2018 Final

\section{TITLE AND SUBTITLE}

5a. CONTRACT NUMBER

Modified Light-Duty AM2 Capability Assessment

5b. GRANT NUMBER

5c. PROGRAM ELEMENT NUMBER

6. AUTHOR(S)

Nolan R. Hoffman and Lyan Garcia

5d. PROJECT NUMBER

470802

5e. TASK NUMBER

5f. WORK UNIT NUMBER

\section{PERFORMING ORGANIZATION NAME(S) AND ADDRESS(ES)}

8. PERFORMING ORGANIZATION REPORT NUMBER

Geotechnical and Structures Laboratory

U.S. Army Engineer Research and Development Center

ERDC/GSL TR-18-10

3909 Halls Ferry Road

Vicksburg, MS 39180-6199

\section{SPONSORING / MONITORING AGENCY NAME(S) AND ADDRESS(ES)}

Headquarters, Air Force Civil Engineer Center

Tyndall Air Force Base, FL 32403-5319

10. SPONSOR/MONITOR'S ACRONYM(S)

AFCEC

11. SPONSOR/MONITOR'S REPORT NUMBER(S)

\section{DISTRIBUTION / AVAILABILITY STATEMENT}

Approved for public release; distribution is unlimited.

\section{SUPPLEMENTARY NOTES}

\section{ABSTRACT}

The Modified Light-Duty AM2 matting was designed specifically for lightweight, remote-piloted aircraft (RPA) applications. An indepth study was conducted previously by the U.S. Army Engineer Research and Development Center (ERDC) to characterize and model the mechanical performance of friction stir welding for use in fabrication of the lightweight RPA matting in conjunction with a full-scale test on the Modified Light-Duty AM2 matting system. The study validated the matting's performance when subjected to simulated RPA and support vehicle traffic over a subgrade with a California Bearing Ratio (CBR) of 6 . To understand the full potential of the Modified Light-Duty AM2, a full-scale evaluation was performed with contingency C-17 and standard (below maximum) F-15E aircraft loads over a subgrade with a CBR of 6 . The test results revealed that the connection between the mat core and the end connector is not strong enough to support loads heavier than RPA traffic. The overlap/underlap end connectors effectively sheared off from the mat core for both test vehicles. Even so, the mat cores showed minimal structural damage from the applied traffic.

\begin{tabular}{|c|c|c|c|c|c|}
\hline \multirow{4}{*}{\multicolumn{2}{|c|}{$\begin{array}{l}\text { 15. SUBJECT TERMS } \\
\text { Airfield matting } \\
\text { AM2 } \\
\text { Trafficability }\end{array}$}} & \multicolumn{2}{|l|}{ Light-duty } & \multicolumn{2}{|c|}{ Runways (Aeronautics) } \\
\hline & & \multicolumn{2}{|c|}{ Friction stir welding } & \multicolumn{2}{|c|}{ Landing mats - Evaluation } \\
\hline & & \multicolumn{2}{|l|}{ Air bases } & \multicolumn{2}{|c|}{ Pavements } \\
\hline & & \multicolumn{2}{|l|}{ Drone aircraft } & \multicolumn{2}{|c|}{ Uninhabited combat aerial vehicles } \\
\hline \multicolumn{3}{|c|}{ 16. SECURITY CLASSIFICATION OF: } & $\begin{array}{l}\text { 17. LIMITATION } \\
\text { OF ABSTRACT }\end{array}$ & $\begin{array}{l}\text { 18. NUMBER } \\
\text { OF PAGES }\end{array}$ & $\begin{array}{l}\text { 19a. NAME OF RESPONSIBLE } \\
\text { PERSON }\end{array}$ \\
\hline $\begin{array}{l}\text { a. REPORT } \\
\text { Unclassified }\end{array}$ & $\begin{array}{l}\text { b. ABSTRACT } \\
\text { Unclassified }\end{array}$ & $\begin{array}{l}\text { c. THIS PAGE } \\
\text { Unclassified }\end{array}$ & & 44 & $\begin{array}{l}\text { 19b. TELEPHONE NUMBER (include } \\
\text { area code) }\end{array}$ \\
\hline
\end{tabular}

